\title{
Identification of Ehrlichia ruminantium proteins that activate cellular immune responses using a reverse vaccinology strategy
}

\author{
J. Liebenberg ${ }^{1,2, *}$, A. Pretorius ${ }^{1}$, F. E. Faber ${ }^{1}$, N. E. Collins ${ }^{2}$, B. A. Allsopp ${ }^{2}$ and M. van Kleef ${ }^{1,2}$
}

\footnotetext{
${ }^{1}$ ARC-Onderstepoort Veterinary Institute, Private Bag X05, Onderstepoort, 0110, South Africa

${ }^{2}$ Department of Veterinary Tropical Diseases, University of Pretoria, Private Bag X04, Onderstepoort, 0110, South Africa
}

\section{*Corresponding Author}

Mailing address: ARC-Onderstepoort Veterinary Institute, Private Bag X5, Onderstepoort, 0110, South Africa

Phone: +27125299425

Fax: +27 125299417

E-mail: LiebenbergJ@ arc.agric.za 


\begin{abstract}
Ehrlichia ruminantium is an obligate intracellular bacterial pathogen which causes heartwater, a serious tick-borne disease of ruminants throughout sub-Saharan Africa. The development of promising recombinant vaccines has been reported previously, but none has been as effective as immunisation with live organisms. In this study we have used reverse vaccinology to identify proteins that elicit an in vitro cellular immune response similar to that induced by intact $E$. ruminantium. The experimental strategy involved four successive steps: (i) in silico selection of the most likely vaccine candidate genes from the annotated genome; (ii) cloning and expression of the selected genes; (iii) in vitro screening of the expressed proteins for their ability to induce interferon-gamma (IFN- $\gamma$ ) production in E. ruminantium-immune lymphocytes; and (iv) further examination of the cytokine response profiles of those lymphocytes which tested positive for IFN- $\gamma$ induction. Based on their overall cytokine induction profiles the recombinant proteins were divided into four distinct groups. Eleven recombinant proteins induced a cytokine profile that was similar to the recall immune response induced by immune peripheral blood mononuclear cells (PBMC) stimulated with intact E. ruminantium. This response comprised the upregulation of cytokines associated with adaptive cellular immune responses as well as innate immunity. A successful vaccine may therefore need to contain a combination of recombinant proteins which induce both immune pathways to ensure protection against heartwater.
\end{abstract}

Keywords: Ehrlichia ruminantium, reverse vaccinology, Th1 cytokines.

Abbreviations: GM-CSF, granulocyte-macrophage colony-stimulating factor; iNOS, inducible nitric oxide synthase; MAP, major antigenic protein; MFT, multifunctional T; MW, molecular weight; NO, nitric oxide; ORFs, open reading frames; qPCR, quantitative real-time PCR; SFC, spot forming cells; SPMC, spots per million cells; TLR, toll-like receptor; th, transmembrane helix. 


\section{Introduction}

E. ruminantium, the causative agent of heartwater, is a Gram-negative $\alpha$-proteobacterium, belonging to the family Anaplasmataceae, order Rickettsiales. All organisms in the order Rickettsiales are obligate intracellular bacteria, and members of the family Anaplasmataceae are located within membrane-bound vacuoles. Heartwater is considered to be one of the most important endemic diseases of domestic livestock in southern Africa, but despite this no safe and effective vaccine is currently available. The only commercially available heartwater immunisation procedure employs the infection and treatment method, using live virulent bacteria, and it has several practical disadvantages as well as offering only limited protection against some common virulent genotypes (Allsopp, 2009).

Heartwater vaccine development has been hindered by technical difficulties, many of which derive from the fact that obligate intracellular bacteria such as E. ruminantium are inherently difficult to study at the molecular genetic level. The availability of the extensively annotated E. ruminantium genome sequence (Collins et al., 2005) allowed us to apply reverse vaccinology (Rappuoli, 2000) in our attempts to develop a vaccine against heartwater. In this approach, potential vaccine candidates with selected criteria can be identified from the whole genome data with the aid of suitable computer algorithms. The most likely candidates are then screened for their ability to induce the appropriate immune responses. Reverse vaccinology was first used to identify vaccine candidates of serogroup B Neisseria meningitidis (Pizza et al., 2000). Since then the technique has been applied in developing vaccines for several other pathogens, some of which are currently in clinical development (Muzzi et al., 2007; Sette \& Rappuoli, 2010).

It has been documented that $\mathrm{CD} 8^{+}$and $\mathrm{CD} 4^{+}$lymphocytes play a role in protection against heartwater in adoptive transfer (Du Plessis et al., 1991) and knock out mice studies (Byrom et al., 2000). Furthermore, when PBMC were obtained from heartwater immune animals an increase in $\mathrm{CD} 4^{+}$and $\mathrm{CD} 8^{+}$lymphocyte proliferation was observed in response to in vitro stimulation with E. ruminantium antigens (Totté et al., 1999; Mwangi et al., 2002). In addition T cell growth factors (Mahan et al., 
1994) and IFN- $\gamma$ (Totté et al., 1996) have been shown to inhibit E. ruminantium growth in vitro. The effect of IFN- $\gamma$ may be due to upregulation of MHC class I and II expression on monocytes leading to increased antigen presentation to immune cells, or by increased phagosytosis, reactive oxygen intermediates, nitric oxide and lysosomal enzyme production. To date the potential roles of antibodies and cytotoxic $\mathrm{T}$ cells have not yet been demonstrated. We hypothesise that heartwater vaccine candidates should be able to elicit a protective cell mediated immune response similar to that induced by live organisms. It has been found that E. ruminantium proteins in the molecular weight ranges 13-18 kDa (Van Kleef et al., 2002) and 22-32 kDa (Esteves et al., 2004) induce IFN- $\gamma$ production, but the specific antigens responsible for this effect have not been identified. Two recombinant E. ruminantium proteins, major antigenic protein (MAP) 1 and MAP2, have been shown to induce T cell lines to produce IFN- $\gamma$ (Mwangi et al., 2002) and protection was observed in mice after DNA immunisation using the map1 gene (Nyika et al., 2002). Similarly, the protective immune response induced in sheep by four other E. ruminantium genes corresponded with increased IFN- $\gamma$ expression (Pretorius et al., 2008). We therefore aimed to identify antigens that induce strong cell mediated immune responses in E. ruminantium-immune $\mathrm{T}$ cells characterised by the expression of IFN- $\gamma$ and other Th1 cytokines.

This communication describes the use of reverse vaccinology to identify potential vaccine candidates for protection against E. ruminantium. Open reading frames (ORFs) with selected criteria were identified from the annotated E. ruminantium (Welgevonden) genome sequence (Collins et al., 2005). The corresponding recombinant proteins were expressed in E. coli and assessed for their ability to induce recall $\mathrm{T}$ cell responses in vitro using E. ruminantium-immune PBMC. 


\section{Materials and methods}

\section{Subcellular localisation prediction of putative gene products}

The E. ruminantium genome annotation (Collins et al., 2005) contains predictions for the subcellular localisation of each putative gene product obtained using the algorithms SignalP (Nielsen et al., 1997) and TMHMM2.0 (Krogh et al., 2001). We refined these predictions using the algorithms Phobius (Käll et al., 2004), PSORTb2.0 (Gardy et al., 2005) and CELLO (Yu et al., 2004) and the new results were used in the subsequent selection procedure.

\section{In silico selection strategy}

The annotation data for each putative E. ruminantium gene product were used as the starting point for the selection procedure. All products classified in the following categories were considered as possible vaccine candidates: surface-associated or secreted proteins, transporters, proteins putatively involved in the adaptation of bacteria to heat shock and other environmental stresses, and proteins of unknown function. We also included proteins containing tandem, tetratricopeptide or ankyrin repeats, as well as those products described as adhesins, proteases, iron-binding proteins, methyltransferases or GTPases. Homologs of proteins identified as vaccine candidates in other pathogens by means of functional genomics were also included. All ORFs with more than four predicted transmembrane helices, genes tested previously in vaccine formulations, and patented ORFs were removed from the dataset.

\section{Expression of recombinant proteins}

\section{Directional cloning into the pET vector}

Protein expression was performed using the pET102/TOPO $^{\circledR}$ expression system (Invitrogen) according to the instructions of the manufacturer. Sequence specific amplification primers were designed for each of the selected ORFs to facilitate directional cloning into the pET vector by adding the sequence CACC to the 5' end of the forward primer and removing the stop codon sequence for the reverse primer. In the case of ORFs having signal peptide coding sequences the 5 ' primers were designed so as to omit the signal sequences. ORFs larger than 2,000 bp were divided into smaller 
subfragments and we also made sure that primer sequences did not overlap large tandem repeat sequences. The ORFs were amplified in a $50 \mu \mathrm{l}$ reaction containing $25 \mathrm{ng}$ E. ruminantium (Welgevonden) genomic DNA, $1.25 \mathrm{U} P f u$ polymerase (Promega), $0.2 \mu \mathrm{M}$ of each primer, $0.2 \mathrm{mM}$ dNTPs, and $1 \mathrm{x}$ reaction buffer (containing $2 \mathrm{mM} \mathrm{Mg}^{2+}$ ). Reaction conditions were: one cycle at $95^{\circ} \mathrm{C}$ for $2 \mathrm{~min}, 35$ cycles of $95^{\circ} \mathrm{C}$ for $30 \mathrm{~s}, 50^{\circ} \mathrm{C}$ for $30 \mathrm{~s}$ and $72^{\circ} \mathrm{C}$ for $3 \mathrm{~min}$, and a final extension at $72^{\circ} \mathrm{C}$ for $7 \mathrm{~min}$. The amplicons were cloned into the $\mathrm{TOPO}^{\circledR} \mathrm{pET}$ vector following the manufacturer's protocols. Clones containing inserts of the correct size were sequenced, using the TrxFus forward and $\mathrm{T} 7$ reverse primers, to verify the orientation and sequences of inserts and to ensure that the His-tag was in-frame.

\section{Expression and purification of recombinant proteins}

Recombinant proteins were expressed using the Overnight Express ${ }^{\mathrm{TM}}$ Autoinduction system 1 (Novagen). The recombinant proteins were extracted from the cell pellets using BugBuster ${ }^{\circledR}$ Protein Extraction Reagent (Novagen) and purified using Protino $^{\circledR} \mathrm{Ni} 1000$ prepacked columns (Macherey-Nagel) following the manufacturer's instructions. The purified proteins were separated on

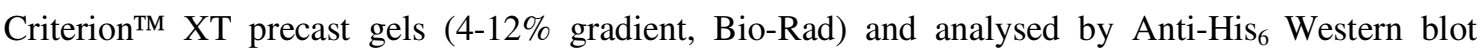
analysis using standard procedures.

\section{Selection of recombinant proteins that induce cellular immunity}

\section{Immune Animals}

Heartwater naïve Merino sheep (s6050) and Nguni cattle (B8460, B8404 and B8347) were immunised by infection with virulent organisms $\left(10 \mathrm{LD}_{50}\right)$ of the Welgevonden stock of E. ruminantium (Brayton et al., 2003). The sheep developed heartwater symptoms and were treated with tetracycline while the cattle showed a mild temperature reaction, but did not show any heartwater symptoms after the initial immunisation, and recovered without treatment. These animals were challenged four months later with the same stock to confirm their immunity to heartwater. The immunity of the cattle was boosted by an additional subcutaneous inoculation of $50 \mu \mathrm{g}$ of inactivated organisms of the Welgevonden 
stock in Montanide ISA50 adjuvant (SEPPIC, France) nine months after the challenge. All animal research was performed in accordance with the stipulations of the animal ethics committee at the ARC-Onderstepoort Veterinary Institute and the University of Pretoria animal use and care committee.

\section{Collection of blood and isolation of PBMC}

Recall immune assays were performed using purified immune PBMC. Blood (50 ml (ovine) or 200 $\mathrm{ml}$ (bovine)) was collected in BD Vacutainer ${ }^{\circledR}$-EDTA tubes (Becton, Dickinson) and PBMC were isolated by density gradient centrifugation (Histopaque ${ }^{\circledR}-1077$; Sigma-Aldrich ${ }^{\circledR}$ ) according to the instructions of the manufacturer. The PBMC were washed three times, live cells were counted using $\mathrm{GIBCO}^{\circledR}$ trypan blue stain (Invitrogen) and the cells resuspended $\left(4 \times 10^{6}\right.$ cells/ml) in cRPMI $\left(\mathrm{GIBCO}^{\circledR} \mathrm{RPMI}^{\mathrm{R}}+\mathrm{GlutaMAX}^{\mathrm{TM}}\right.$-I (Invitrogen) supplemented with $55 \mathrm{mM}$ 2-mercaptoethanol and $1 \%$ GIBCO $^{\circledR}$ Pen Strep (Invitrogen)).

\section{IFN- $\gamma$ ELISPOT assays}

IFN- $\gamma$ expression was measured by ELISPOT assays as described previously (Sebatjane et al., 2010). Briefly, ELISPOT plates (Millipore) were coated with mouse anti-bovine IFN- $\gamma$ mAb CC302 (1 $\mu \mathrm{g} / \mathrm{ml})$. After blocking the plates with RPMI-1640 supplemented with $10 \%$ FCS, PBMC $\left(2 \times 10^{5}\right.$ cells/well) were incubated with the recombinant proteins $(10 \mu \mathrm{g} / \mathrm{ml} ; 1 \mu \mathrm{g} / \mathrm{ml}$ or $0.1 \mu \mathrm{g} / \mathrm{ml})$, or partially purified intact E. ruminantium (Welgevonden) organisms isolated from infected bovine endothelial cells ( $1 \mu \mathrm{g} / \mathrm{well}$, positive antigen), or uninfected bovine endothelial cell extract $(1 \mu \mathrm{g} / \mathrm{well}$, negative antigen) in a total volume of $100 \mu \mathrm{l}$. PBMC stimulated with ConA ( $5 \mu \mathrm{g} / \mathrm{ml}$, Sigma) were included as a positive control, while wells containing PBMC without antigen were used as a negative control. The plates were developed as described by Sebatjane et al. (2010) and spot forming cells (SFC) were enumerated using an automated ELISPOT reader (Zeiss KS ELISPOTCompact 4.5). The number of SFC produced after stimulation of immune PBMC with the recombinant proteins was compared to the number of SFC produced by immune PBMC without antigen. ELISPOT samples 
with $4 \mathrm{x}$ the number of spots per million cells (SPMC) compared to the non-stimulated cells were considered positive.

\section{Cytokine profiling using quantitative real-time PCR (qPCR)}

Isolated PBMC (sheep or bovine) were resuspended in complete RPMI-1640 medium and cells $\left(4 \times 10^{6}\right.$ cells $/ \mathrm{ml}$, final concentration) were stimulated with the expressed recombinant proteins (10 $\mu \mathrm{g} / \mathrm{ml} ; 1 \mu \mathrm{g} / \mathrm{ml}$ or $0.1 \mu \mathrm{g} / \mathrm{ml}$ ) or incubated in medium alone for approximately $18 \mathrm{~h}$ (overnight). Cells were harvested by centrifugation at $300 \mathrm{~g}$ and $\mathrm{TRI}^{\circledR}$-Reagent (Sigma-Aldrich ${ }^{\circledR}$ ) was added to each sample. These samples were kept at $-70^{\circ} \mathrm{C}$ until total RNA was isolated according to the TRI $^{\circledR}$-Reagent protocol. The mRNA quality was assessed by agarose gel electrophoresis and contaminating genomic DNA was removed by using the DNA-free kit (Ambion) according to the instructions of the manufacturer. Single stranded cDNA was generated using Expand reverse transcriptase $(2.5 \mathrm{U} / \mu \mathrm{l}$ final concentration; Roche) and random hexamer primers $(12.5 \mu \mathrm{g} / \mu \mathrm{l}$ final concentration) (Promega). PCR was performed using the LightCycler ${ }^{\circledR}$ FastStart DNA Master ${ }^{\text {PLUS }}$ SYBR Green 1 kit (Roche) according to the manufacturer's instructions. Cytokine primers used were previously optimised for bovine mRNA: IL-1 $\alpha$, IL-18, toll-like receptor (TLR) 2 and TLR4 (Lahmers et al., 2006); IL-4, IL-10, IFN- $\gamma$, TNF- $\alpha$ and inducible nitric oxide synthase (iNOS) (Thacker et al., 2007); IL-6, IL-8, IL-12p40 and granulocyte-macrophage colony-stimulating factor (GM-CSF) (Lee et al., 2006) and GAPDH (Claerebout et al., 2005). Ovine qPCR primers were: IFN- $\gamma$, IL-4 and GAPDH (Pretorius et al., 2008); IL-8 and IL-1 $\alpha$ (Smeed et al., 2007); IL-18 (Markus et al., 2007) and TNF- $\alpha$ (Budhia et al., 2006). qPCR cycling conditions for all the cytokines were: $10 \mathrm{~min}$ at $94^{\circ} \mathrm{C} ; 50$ cycles of $15 \mathrm{~s}$ at $94^{\circ} \mathrm{C}, 30 \mathrm{~s}$ at $58^{\circ} \mathrm{C}$ and $20 \mathrm{~s}$ at $72^{\circ} \mathrm{C}$; followed by melting starting at $65^{\circ} \mathrm{C}$ rising to $95^{\circ} \mathrm{C}$ at $0.3^{\circ} \mathrm{C}$ per second; and cooling to $40^{\circ} \mathrm{C}$. Relative quantitation was determined with the $2^{-\Delta \Delta \mathrm{Ct}}$ method (Livak \& Schmittgen, 2001). Gene expression was reported as the normalised cycle threshold $\left(\Delta \mathrm{Ct}=\mathrm{Ct}\right.$ target gene $-\mathrm{Ct}$ housekeeping gene and $\left.\Delta \Delta \mathrm{Ct}=\Delta \mathrm{Ct}_{\text {stimulated }}-\Delta \mathrm{Ct}_{\text {medium }}\right) . \quad \mathrm{A}$ one-fold increase indicates that the cytokine mRNA concentration of the stimulated sample is twice that of non-stimulated samples, and the cytokines were considered to be significantly upregulated if the mRNA increase difference was more than one-fold. 


\section{Results}

\section{Subcellular localisation of ORFs}

The algorithm SignalP predicted that 66 E. ruminantium ORFs showed 5' sequences coding for Nterminal signal peptides, of which 13 also contained one or two predicted transmembrane helices. According to the TMHMM results $28 \%$ (247) of all ORFs in the E. ruminantium genome are predicted to contain at least one transmembrane helix. Forty-eight of these transmembrane helices were also predicted to be signal sequences by SignalP. When compared with the results of another algorithm, Phobius, 15 of the 48 transmembrane helices were in fact predicted to code for signal peptides. Two additional algorithms, pSORTb and CELLO, were utilised to assist in the assignment of proteins to subcellular locations (Figure 1). However the results varied significantly between the two algorithms with only $39 \%$ of the putative proteins being assigned to the same location by both programs. The majority of the shared predictions were for allocations to the cytoplasm (217 ORFs) and inner membrane (109 ORFs). Only 20 of the 888 putative proteins were predicted by both algorithms to be in the outer membrane.

\section{In silico selection of possible vaccine candidates}

ORFs coding for proteins with functional or structural similarity to proven protective antigens or known bacterial virulence factors, plus all putative proteins of unknown function, were identified from the annotated E. ruminantium (Welgevonden) genome sequence. In the E. ruminantium annotation database, 521 out of 888 putative protein coding genes have an assigned biological function. From these we selected all ORFs in the functional categories transporters, proteins involved in protection responses and adaptation, chaperones and proteases (98 ORFs in total). In addition we searched the rest of the annotation data for genes coding for adhesins, iron-binding proteins, methyltransferases and GTPases. From the ORFs that did not show any sequence similarity to wellcharacterised proteins we selected all ORFs classified as membrane-associated or exported proteins (175 in total), as well as ORFs for which no functional or structural information was available (141

ORFs). The selection was aided by the subcellular localisation predictions of the programs CELLO 
and PSORTb. ORFs containing tandem, tetratricopeptide or ankyrin repeats were specifically included. Finally five homologs of proteins which have been described as being immunogenic or protective in other organisms were included in the list of 419 ORFs (Table 1, round 1). The number of candidates was reduced to 272 (Table 1, round 2; Table S1, Supporting information) by eliminating patented genes (United States Patent 6,593,147; Barbet et al., 2001) and ORFs tested previously (Louw et al., 2002; Nyika et al., 2002; Pretorius et al., 2002; 2007). ORFs with more than four predicted transmembrane helices were also excluded for purely practical reasons, since these are often difficult to express (Pizza et al., 2000; Ariel et al., 2003).

\section{Expression and selection of recombinant proteins that induce specific Th1 cellular immune responses}

Several of the selected 272 ORFs were amplified as smaller subfragments to facilitate expression in $E$. coli, giving a total of 283 genes plus subfragments. The products of 228 of these were successfully expressed, purified either in a water-soluble form or as insoluble inclusion bodies, and used in IFN- $\gamma$ ELISPOT assays. Initially the PBMC obtained from a heartwater immune sheep (s6050) were used to screen 38 of the recombinant proteins. PBMC isolated from $50 \mathrm{ml}$ of blood from this animal (the maximum amount of blood ethically permitted per bleed) did not yield enough cells to screen all 228 recombinant proteins. The remainder of the recombinant proteins (190) were therefore screened at three different concentrations using PBMC isolated from three immune cattle. IFN- $\gamma$ producing cells were induced by 3 out of 38 recombinant proteins tested using immune sheep PBMC, and by 32 of the 190 recombinant proteins in PBMC isolated from cattle. The number of IFN- $\gamma$ SPMC for positive samples were significantly higher than those for non-stimulated PBMC and for those that did not induce IFN- $\gamma$ in immune PBMC. The recombinant proteins that did not induce detectable IFN- $\gamma$ protein were further screened using qPCR for their ability to induce the transcription of IFN- $\gamma$ mRNA using the same bovine PBMC and protein concentrations as those used in the ELISPOT assay. This yielded an additional 11 recombinant proteins that induced low levels of IFN- $\gamma$ mRNA. 
All 46 of the recombinant proteins that induced either IFN- $\gamma$ or its transcript were screened for their ability to induce additional cytokines in the same sheep or bovine PBMC samples which had shown induced IFN- $\gamma$ at optimum concentration. Additional cytokines were induced by 26 of these IFN- $\gamma$ inducing proteins (Table 2). Based on their overall cytokine induction profiles the proteins could be divided into four separate groups designated A to D. Proteins which induced cytokine profile A in bovine PBMC induced early increase in IFN- $\gamma$ mRNA levels (1-8 fold after $4 \mathrm{~h}$ incubation) which significantly increased to 16-809 fold overnight. With some exceptions, the upregulation of IFN- $\gamma$ mRNA coincided with increased mRNA levels of iNOS; TNF- $\alpha$; IL-1 $\alpha$; IL-18 and GM-CSF. In addition, increased levels of IL-4 and IL-10 mRNA were detected after stimulation with recombinant proteins coded by Erum7280, -7620 and -8010 , but the IFN- $\gamma$ :IL-4 mRNA ratios $(246: 10 ; 809: 7$; and 33:5 respectively) remained polarised towards Th1 cellular immunity. Cytokine profile A was, except for the absence of TLR2 expression, similar to that induced by intact E. ruminantium in two of the cattle tested. PBMC stimulated with intact E. ruminantium had high levels of overnight IFN- $\gamma$ mRNA (64 and 232 fold increase), that corresponded with high levels of IFN- $\gamma$ protein (200 and 985 SPMC). In contrast, in spite of the high levels of IFN- $\gamma$ mRNA induced by Erum7280, and -7620, (246 and 809 fold increase respectively) low levels of IFN- $\gamma$ (20 and 48 SPMC) were detected with ELISPOT. The recombinant proteins inducing cytokine profile A were the only proteins shown to induce IFN- $\gamma$ mRNA transcripts after overnight incubation. Although not measured after $4 \mathrm{~h}$, increased levels of IFN- $\gamma$ mRNA were also detected after overnight incubation when three recombinant proteins, coded by Erum5270, -5400 and -8050 , were tested using sheep PBMC. All three of these proteins also induced upregulation of IFN- $\gamma$, TNF- $\alpha$, IL- $1 \alpha$, and IL-18 mRNA in immune PBMC stimulated overnight with $1 \mu \mathrm{g} / \mathrm{ml}$ protein (Table 2). Hence, these three proteins were also grouped into cytokine profile A. Characteristics of all the proteins in cytokine profile A are summarised in Table 3.

Four recombinant proteins (coded by Erum1040_3; -1050; -1990; -8510) induced cytokine profile B. IFN- $\gamma$ protein expression levels were similar to those induced by proteins that induced cytokine profile A. However, cytokine profile B recombinant proteins induced increased IFN- $\gamma$ mRNA transcription at $4 \mathrm{~h}$ after stimulation, but IFN- $\gamma$ mRNA expression was much lower, or completely 
absent, after overnight incubation (Table 2). A decrease in mRNA levels between the $4 \mathrm{~h}$ and overnight samples was also detected for TNF- $\alpha$; IL-18; iNOS and GM-CSF.

Proteins that induced cytokine profiles $\mathrm{C}$ and D did not induce IFN- $\gamma$ but did induce IFN- $\gamma$ mRNA transcripts. These two profiles were also similar to cytokine profile B in that IFN- $\gamma$ mRNA expression could be measured after $4 \mathrm{~h}$ but was decreased or absent after overnight incubation. Proteins that induced cytokine profile C also induced high levels of IL-18; GM-CSF; iNOS and IL-8, while proteins in cytokine profile D induced TNF- $\alpha$; GM-CSF; iNOS and IL- $1 \alpha$ after $4 \mathrm{~h}$ incubation.

\section{Discussion}

The purpose of this work was to identify E. ruminantium vaccine candidates that induce immune responses similar to those induced by whole organisms. Our approach involved four steps: (i) in silico selection from the annotated genome; (ii) cloning of selected genes, and the expression and purification of the corresponding recombinant proteins; (iii) identification of recombinant proteins that induce IFN- $\gamma$ production in ELISPOT and/or qPCR assays; and (iv) cytokine profiling of IFN- $\gamma$ inducing recombinant proteins using qPCR.

A large part of our initial in silico selection consisted of putative proteins of unknown function, as well as surface-associated and exported proteins. Although surface-exposed antigens are associated with humoral responses, surface-associated proteins of intracellular pathogens have been reported to elicit $\mathrm{CD}^{+}$and/or $\mathrm{CD}^{+}$responses (Sampson, 2011). We employed several programs to predict the subcellular location of putative proteins, but there was very little agreement between the different algorithms. Other workers have reported this situation (Sprenger et al., 2006), and without experimental evidence it is not possible to determine which algorithm is the superior predictor. In addition, it is currently impossible to predict how changing conditions in vivo will affect the expression of different membrane components (Grandi, 2003). One must therefore be cautious in the interpretation of localisation predictions, but algorithms are constantly improving (Choo et al., 2009; 
Yu et al., 2010) and more experimental data are becoming available, hence future predictions ought to be more reliable.

Many E. ruminantium proteins of unknown function, and some of the membrane-associated proteins, contained tetratricopeptide or ankyrin repeat domains or tandem repeats. All three repeat elements have been implicated in host-pathogen interactions (Core \& Perego, 2003; De la Fuente et al., 2004; Wakeel et al., 2010; Zhu et al., 2009), hence these genes may be considered as vaccine candidates. Other possibly important categories for protection against bacterial infection include type IV secretion system proteins (Lopez et al., 2007; Juhas et al., 2008), transporters, particularly the ABC transport system (Brown et al., 2001; Pretorius et al., 2007; Roset et al., 2004) and proteases (Miyoshi \& Shinoda, 2000; Ariel et al., 2003, Myers et al., 2007).

$\mathrm{T}$ cell responses characterised by the expression of IFN- $\gamma$ are essential in protection against E. ruminantium infection (Totté et al. 1999; Mwangi et al., 2002) which was the rationale behind attempting to determine whether any of our E. ruminantium recombinant proteins induced IFN- $\gamma$ production in E. ruminantium-immune lymphocytes in vitro. Initially ELISPOT and qPCR assays used sheep PBMC, but later PBMC isolated from three immune cattle were used as more cells could be harvested from the cattle and the bovine PBMC gave lower background stimulation values. In general, the PBMC isolated from one of the animals responded to a specific protein tested at a given time point. Outbred cattle and sheep were used in this study each with unique MHC alleles (personal communication, N. Thema), thus these genetic differences may result in immune response variations as has been found in other studies using outbred animals (Babiuk et al., 2003). Another factor to consider is that the E. ruminantium specific lymphocytes may have been present in the blood at concentrations too low to allow effective measurement, or were not circulating at the time of isolation (Kennedy et al., 2002). A better correlation between the three bovine PBMC and the selection of additional IFN- $\gamma$ producing proteins may be achieved by repeating the immune assays at more than one time point. The use of $\mathrm{T}$ 
cell lines specific to each recombinant protein would yield more sensitive and specific data and will in future be used for testing the most promising vaccine candidates. A total of 228 expressed recombinant proteins were assayed using immune sheep or bovine PBMC. Either soluble and/or insoluble fractions were included because insolubility and protein denaturation usually do not affect the outcome of cellular immunological assays (Leung et al., 2004). Although the recombinant proteins had been purified to differing degrees all indications were that the positive responses obtained were E. ruminantium specific. A total of 35 recombinant proteins could induce IFN- $\gamma$ mRNA and protein in either sheep or bovine PBMC, while 11 recombinant proteins induced IFN- $\gamma$ mRNA only (bovine PBMC). The cytokine profiles of these 46 IFN- $\gamma$-inducing recombinant proteins were determined and compared to those induced after stimulation with intact E. ruminantium.

The cytokine profile induced in immune bovine PBMC by intact $E$. ruminantium (cytokine profile A) was characterised by increased IFN- $\gamma$; TNF- $\alpha$ and iNOS mRNA from $4 \mathrm{~h}$ to overnight. iNOS expression is induced after IFN- $\gamma$ and/or TNF- $\alpha$ /receptor interaction (Goff et al., 2002; Bogdan, 2001) and regulates the production of nitric oxide (NO) that is detrimental to intracellular pathogens (Kobayashi, 2010). The toll-like receptors TLR4 and TLR2 mRNAs are also upregulated in the presence of IFN- $\gamma$ and TNF- $\alpha$ (Winder et al., 2009) and induce innate immunity (Werling et al., 2006). Intact E. ruminantium also induced myeloid-specific cytokine mRNAs including IL-18; IL-1 $\alpha$; IL-6 and GM-CSF. TNF- $\alpha$, IL-12 and IL-18 may also, in synergy with IL-2 produced by CD4 ${ }^{+}$T cells after interaction with antigen presenting cells, induce a recall NK cell response that is essential for early pathogen clearance (Horowitz et al., 2010). Activated NK cells are an important source of IFN- $\gamma$ during early recall immune responses in both viral (Horowitz et al., 2010) and intracellular bacterial infections (Haeberlein et al., 2010; Humann \& Lenz, 2010; Waters et al., 2011). IL-4 and IL-10 cytokine mRNAs were also upregulated by intact E. ruminantium. The IL-4 secretion might indicate humoral immune activation, but it is more likely that IL-10 and IL-4 are produced to regulate high levels of NO (Bogdan, 2001; Goff et al., 2002). Pro-inflammatory cytokines and chemokines (IL-6 and IL-8), also detected in intact E. ruminantium-stimulated PBMC, assist in the recruitment 
and activation of immune cells (Lee et al., 2004). Protective immunity against E. ruminantium may therefore be mediated not only by $\mathrm{CD} 4^{+}$and $\mathrm{CD} 8^{+} \mathrm{T}$ cells producing IFN- $\gamma$ and TNF- $\alpha$ (Totté et al., 1999), but may also require activation of other immune pathways, such as recall NK cell responses and innate immunity mediated by specific cytokines and chemokines. Thus, the vaccine candidates selected should induce these appropriate cytokines and the final vaccine formulation should activate both innate and cellular immunity.

Cytokine profile A was measured for a total of 11 recombinant proteins (Table 3), three that were selected using sheep PBMC and eight that were selected using bovine PBMC. These were the only recombinant proteins which induced IFN- $\gamma$ protein production that correlated with relatively low levels of IFN- $\gamma$ mRNA at $4 \mathrm{~h}$ that increased markedly overnight. These recombinant proteins also induced elevated TNF- $\alpha$, GM-CSF, iNOS and TLR4 expression. IFN- $\gamma$ protein expression was however at lower levels than that induced by intact E. ruminantium. All of these IFN- $\gamma$ inducing proteins, with the exception of those coded by Erum0660_1 and Erum8050, were of low molecular weight, correlating with previous studies indicating that low molecular weight E. ruminantium proteins induced IFN- $\gamma$ production (Van Kleef et al., 2002; Esteves et al., 2004; Sebatjane et al., 2010). Cytokine profile A proteins could also induce TLR4, probably via IFN- $\gamma$ and TNF- $\alpha$ induction. Proteins that induce the activation of these receptors may thus be useful in the promotion of innate immunity when included as part of a vaccine against heartwater. Recombinant proteins inducing cytokine profiles $\mathrm{C}$ and $\mathrm{D}$ may also be useful in vaccine formulations. Cytokine profile $\mathrm{C}$ proteins induced high levels of IL-18, a cytokine important for IFN- $\gamma$ production and the development of memory CTLs (Iwai et al., 2008). In contrast, relatively low levels of IL-18 mRNA were detected in PBMC stimulated with intact E. ruminantium; this may be attributed to the presence of IL-18 inhibitory proteins similar to those found for E. chaffeensis (Wakeel et al., 2010). This down regulation will possibly reduce any CTL response directed against E. ruminantium antigen, thus promoting survival of the pathogen. Recombinant proteins that induced cytokine profile $\mathrm{C}$ and $\mathrm{D}$ also induced GM-CSF, a cytokine used in DNA vaccines targeted to dendritic cells (DC-based vaccines) (Le et al., 2010). 
It should be noted that IFN- $\gamma$ expression alone is not always indicative of protection against E. ruminantium infection in vivo (Vachiéry et al., 2006). Recent studies on protective immunity against Mycobacterium tuberculosis have shown a better correlation between protection and the number of multifunctional T (MFT) cells which were detected in immune pulmonary and spleen cell preparations (Derrick et al., 2011). MFT cells are single cells that produce high concentrations of the cytokines IFN- $\gamma$; TNF- $\alpha$ and IL-2. Although we did not determine multiple cytokines produced by a single $\mathrm{T}$ cell using flow cytometry, the recombinant proteins in cytokine profile A did show simultaneous upregulation of IFN- $\gamma$ and TNF- $\alpha$. These proteins are therefore the most likely to induce protective immunity to heartwater. Future studies should focus on determining whether both of these cytokines are produced by the same $\mathrm{CD}^{+} \mathrm{T}$ cell and whether the activation of these MFT cells is linked to protection against heartwater.

In conclusion, using a reverse vaccinology strategy, we could select recombinant proteins that induced a cellular immune response in immune bovine PBMC that was similar to the response induced by intact E. ruminantium. It remains to be determined whether these antigens are capable of inducing protective immune responses against heartwater infection in vivo. It is likely that a future recombinant vaccine formulation should contain genes and/or proteins that induce the different immune pathways induced by intact organisms.

\section{Acknowledgements}

This work was supported by the South African Department of Agriculture OV9/23/C167 grant and the FP6 EU INCO-DEV EPIGENEVAC FP6-003713 grant. 


\section{References}

Allsopp, B.A., 2009. Trends in the control of heartwater. Onderstepoort J. Vet. Res. 76, 81-88.

Ariel, N., Zvi, A., Makarova, K.S., Chitlaru, T., Elhanany, E., Velan, B., Cohen, S., Friedlander, A.M., Shafferman, A., 2003. Genome-based bioinformatic selection of chromosomal Bacillus anthracis putative vaccine candidates coupled with proteomic identification of surface-associated antigens. Infect. Immun. 71, 4563-4579.

Babiuk, L.A., Pontarollo, R., Babiuk, S., Loehr, B., Van Drunen Littel-Van Den Hurk, S., 2003. Induction of immune responses by DNA vaccines in large animals. Vaccine. 21, 649-658.

Barbet, A.F., Whitmire, W.M., Kamper, S.M., Simbi, B.H., Ganta, R.R., Moreland, A.L., Mwangi, D.M., McGuire, T.C., Mahan, S.M., 2001. A subset of Cowdria ruminantium genes important for immune recognition and protection. Gene 275, 287-298.

Bogdan, C., 2001. Nitric oxide and the immune response. Nature Immunol. 2, 907-916.

Brayton, K.A., Collins, N.E., van Strijp, F., Allsopp, B.A., 2003. Preparation of Ehrlichia ruminantium challenge material for quantifiable and reproducible challenge in mice and sheep. Vet. Parasitol. 112, 63-73.

Brown, J.S., Ogunniyi, A.D., Woodrow, M.C., Holden, D.W., Paton, J.C., 2001. Immunization with components of two iron uptake $\mathrm{ABC}$ transporters protects mice against systemic Streptococcus pneumoniae infection. Infect. Immun. 69, 6702-6706.

Budhia, S., Haring, L.F., McConnell, I., Blacklaws, B.A., 2006. Quantitation of ovine cytokine mRNA by real-time RT-PCR. J. Immunol. Methods 309, 160-172.

Byrom, B., Barbet, A.F., Obwolo, M., Mahan, S.M., 2000. CD8(+) T cell knockout mice are less susceptible to Cowdria ruminantium infection than athymic, CD4(+) T cell knockout, and normal C57BL/6 mice. Vet. Parasitol. 93, 159-172. 
Choo, K.H., Tan, T.W., Ranganathan, S., 2009. A comprehensive assessment of N-terminal signal peptides prediction methods. BMC Bioinformatics 10, S2.

Claerebout, E., VerCauteren, I., Geldhof, P., Olbrechts, A., Zarlenga, D.S., Goddeeris, B.M., Vercruysse, J., 2005. Cytokine responses in immunized and non-immunized calves after Ostertagia ostertagi infection. Parasite Immunol. 27, 325-331.

Collins, N.E., Liebenberg, J., de Villiers, E.P., Brayton, K.A., Louw, E., Pretorius, A., Faber, F.E., van Heerden, H., Josemans, A., van Kleef, M., Steyn, H.C., van Strijp, M.F., Zweygarth, E., Jongejan, F., Maillard, J.C., Berthier, D., Botha, M., Joubert, F., Corton, C.H., Thomson, N.R., Allsopp, M.T., Allsopp, B.A., 2005. The genome of the heartwater agent Ehrlichia ruminantium contains multiple tandem repeats of actively variable copy number. Proc. Natl. Acad. Sci. U. S. A. 102, 838-843.

Core, L., Perego, M., 2003. TPR-mediated interaction of RapC with ComA inhibits response regulator-DNA binding for competence development in Bacillus subtilis. Mol. Microbiol. 49, 1509-1522.

De la Fuente, J., Garcia-Garcia, J.C., Barbet, A.F., Blouin, E.F., Kocan, K.M., 2004. Adhesion of outer membrane proteins containing tandem repeats of Anaplasma and Ehrlichia species (Rickettsiales: Anaplasmataceae) to tick cells. Vet. Microbiol. 98, 313-322.

Derrick, S.C., Yabe, I.M., Yang, A., Morris, S.L., 2011. Vaccine-induced anti-tuberculosis protective immunity in mice correlates with the magnitude and quality of multifunctional CD4 T cells. Vaccine 29, 2902-2909.

Du Plessis, J.L., Berche, P., Van Gas, L., 1991. T cell-mediated immunity to Cowdria ruminantium in mice: the protective role of Lyt-2+ T cells. Onderstepoort J. Vet. Res. 58, 171-179.

Esteves, I., Martinez, D., Totté, P., 2004. Identification of Ehrlichia ruminantium (Gardel strain) IFN-gamma inducing proteins after vaccination with a killed vaccine. Vet. Microbiol. 100, 233-240. 
Gardy, J.L., Laird, M.R., Chen, F., Rey, S., Walsh, C.J., Ester, M., Brinkman, F.S., 2005. PSORTb v.2.0: expanded prediction of bacterial protein subcellular localization and insights gained from comparative proteome analysis. Bioinformatics 21, 617-623.

Goff, W.L., Johnson, W.C., Parish, S.M., Barrington, G.M., Elsasser, T.H., Davis, W.C., Valdez, R.A., 2002. IL-4 and IL-10 inhibition of IFN-gamma- and TNF-alpha-dependent nitric oxide production from bovine mononuclear phagocytes exposed to Babesia bovis merozoites. Vet. Immunol. Immunopathol. 84, 237-251.

Grandi, G., 2003. Rational antibacterial vaccine design through genomic technologies. Int. J. Parasitol. 33, 615-620.

Haeberlein, S., Sebald, H., Bogdan, C., Schleicher, U., 2010. IL-18, but not IL-15, contributes to the IL-12-dependent induction of NK-cell effector functions by Leishmania infantum in vivo. Eur. J. Immunol. 40, $1708-1717$.

Horowitz, A., Behrens, R.H., Okell, L., Fooks, A.R., Riley, E.M., 2010. NK cells as effectors of acquired immune responses: effector CD4+ $\mathrm{T}$ cell-dependent activation of NK cells following vaccination. J. Immunol. 185, 2808-2818.

Humann, J., Lenz, L.L., 2010. Activation of naive NK cells in response to Listeria monocytogenes requires IL-18 and contact with infected dendritic cells. J. Immunol. 184, 5172-5178.

Iwai, Y., Hemmi, H., Mizenina, O., Kuroda, S., Suda, K., Steinman, R.M., 2008. An IFN-gamma-IL-18 signaling loop accelerates memory CD8+ T cell proliferation. PLoS One 3, e2404.

Juhas, M., Crook, D.W., Hood, D.W., 2008. Type IV secretion systems: tools of bacterial horizontal gene transfer and virulence. Cell Microbiol. 10, 2377-2386.

Käll, L., Krogh, A., Sonnhammer, E.L., 2004. A combined transmembrane topology and signal peptide prediction method. J. Mol. Biol. 338, 1027-1036. 
Kennedy, H.E., Welsh, M.D., Bryson, D.G., Cassidy, J.P., Forster, F.I., Howard, C.J., Collins, R.A., Pollock, J.M., 2002. Modulation of immune responses to Mycobacterium bovis in cattle depleted of $\mathrm{WC}^{+} \gamma \delta \mathrm{T}$ cells. Infect. Immun. 70, 1488-1500.

Kobayashi, Y., 2010. The regulatory role of nitric oxide in proinflammatory cytokine expression during the induction and resolution of inflammation. J. Leukoc. Biol. 88, 1157-1162.

Krogh, A., Larsson, B., von Heijne, G., Sonnhammer, E.L., 2001. Predicting transmembrane protein topology with a hidden Markov model: application to complete genomes. J. Mol. Biol. 305, 567-580.

Lahmers, K.K., Hedges, J.F., Jutila, M.A., Deng, M., Abrahamsen, M.S., Brown, W.C., 2006. Comparative gene expression by $\mathrm{WC}^{+} \gamma \delta$ and $\mathrm{CD}^{+} \alpha \beta$ T lymphocytes, which respond to Anaplasma marginale, demonstrates higher expression of chemokines and other myeloid cell-associated genes by $\mathrm{WC}^{+} \gamma \delta \mathrm{T}$ cells. J. Leukoc. Biol. 80, 939-952.

Le, D.T., Pardoll, D.M., Jaffee, E.M., 2010. Cellular vaccine approaches. Cancer J. 16, 304-310.

Lee, J-K., Kim, S-H., Lewis, E.C., Azam, T., Reznikov, L.L., Dinarello, C.A., 2004. Differences in signaling pathways by IL-1 $\beta$ and IL-18. Proc. Natl. Acad. Sci. U. S. A. 101, 8815-8820.

Lee, J-W., Bannerman, D.D., Max J. Paape, M.J., Huang, M-K., Zhao, X., 2006. Characterization of cytokine expression in milk somatic cells during intramammary infections with Escherichia coli or Staphylococcus aureus by real-time PCR. Vet. Res. 37, 219-229.

Leung, W.H., Meng, Z.Q., Hui, G., Ho, W.K., 2004. Expression of an immunologically reactive merozoite surface protein (MSP-1 ${ }_{42}$ ) in E. coli. Biochim. Biophys. Acta 1675, 62-70.

Livak, K.J., Schmittgen, T.D., 2001. Analysis of relative gene expression data using real-time quantitative PCR and the 2(-Delta Delta C (T)) method. Methods 25, 402-408. 
Lopez, J.E., Palmer, G.H., Brayton, K.A., Dark, M.J., Leach, S.E., Brown, W.C., 2007. Immunogenicity of Anaplasma marginale type IV secretion system proteins in a protective outer membrane vaccine. Infect. Immun. 75, 2333-2342.

Louw, E., Brayton, K.A., Collins, N.E., Pretorius, A., Van Strijp, F., Allsopp, B.A., 2002. Sequencing of a 15-kb Ehrlichia ruminantium clone and evaluation of the cpgl open reading frame for protection against heartwater. Ann. N. Y. Acad. Sci. 969, 147-150.

Mahan, S.M., Smith, G.E. and Byrom, B., 1994. Concanavalin A stimulated bovine T-cell supernatants inhibit growth of Cowdria ruminantium in bovine endothelial cells in vitro. Infect. Immun. 62, 747-750.

Markus, T., Hansson, S., Amer-Wåhlin, I., Hellström-Westas, L., Saugstad, O.D., Ley, D., 2007. Cerebral inflammatory response after fetal asphyxia and hyperoxic resuscitation in newborn sheep. Pediatr. Res. 62, 71-77.

Miyoshi, S., Shinoda, S., 2000. Microbial metalloproteases and pathogenesis. Microbes Infect. 2, 91-98.

Muzzi, A., Masignani, V., Rappuoli, R., 2007. The pan-genome: towards a knowledge-based discovery of novel targets for vaccines and antibacterials. Drug Discov. Today 12, 429-439.

Mwangi, D.M., McKeever, D.J., Nyanjui, J.K., Barbet, A.F., Mahan, S.M., 2002. Immunisation of cattle against heartwater by infection with Cowdria ruminantium elicits $\mathrm{T}$ lymphocytes that recognise major antigenic proteins 1 and 2 of the agent. Vet. Immunol. Immunopathol. 85, 23-32.

Myers, G.S., Parker, D., Al-Hasani, K., Kennan, R.M., Seemann, T., Ren, Q., Badger, J.H., Selengut, J.D., Deboy, R.T., Tettelin, H., Boyce, J.D., McCarl, V.P., Han, X., Nelson, W.C., Madupu, R., Mohamoud, Y., Holley, T., Fedorova, N., Khouri, H., Bottomley, S.P., Whittington, R.J., Adler, B., Songer, J.G., Rood, J.I., Paulsen, I.T., 2007. Genome sequence and identification of candidate vaccine antigens from the animal pathogen Dichelobacter nodosus. Nat. Biotechnol. 25, 569-575. 
Nielsen, H., Engelbrecht, J., Brunak, S., von Heijne, G., 1997. Identification of prokaryotic and eukaryotic signal peptides and prediction of their cleavage sites. Protein Eng. 10, 1-6.

Nyika, A., Barbet, A.F., Burridge, M.J., Mahan, S.M., 2002. DNA vaccination with mapl gene followed by protein boost augments protection against challenge with Cowdria ruminantium, the agent of heartwater. Vaccine 20, 1215-1225.

Pizza, M., Scarlato, V., Masignani, V., Giuliani, M.M., Aricò, B., Comanducci, M., Jennings, G.T., Baldi, L., Bartolini, E., Capecchi, B., Galeotti, C.L., Luzzi, E., Manetti, R., Marchetti, E., Mora, M., Nuti, S., Ratti, G., Santini, L., Savino, S., Scarselli, M., Storni, E., Zuo, P., Broeker, M., Hundt, E., Knapp, B., Blair, E., Mason, T., Tettelin, H., Hood, D.W., Jeffries, A.C., Saunders, N.J., Granoff, D.M., Venter, J.C., Moxon, E.R., Grandi, G., Rappuoli, R., 2000. Identification of vaccine candidates against serogroup B meningococcus by whole-genome sequencing. Science 287, 1816-1820.

Pretorius, A., Van Strijp, F., Brayton, K.A., Collins, N.E., Allsopp, B.A., 2002. Genetic immunization with Ehrlichia ruminantium GroEL and GroES homologues. Ann. N. Y. Acad. Sci. 969, 151-154.

Pretorius, A., Collins, N.E., Steyn, H.C., van Strijp, F., van Kleef, M., Allsopp, B.A., 2007. Protection against heartwater by DNA immunisation with four Ehrlichia ruminantium open reading frames. Vaccine 25, 2316-2324.

Pretorius, A., van Kleef, M., Collins, N.E., Tshikudo, N., Louw, E., Faber, F.E., van Strijp, M.F., Allsopp, B.A., 2008. A heterologous prime/boost immunisation strategy protects against virulent E. ruminantium Welgevonden needle challenge but not against tick challenge. Vaccine 26, 4363-4371.

Rappuoli, R., 2000. Reverse vaccinology. Curr. Opin. Microbiol. 3, 445-450. 
Roset, M.S., Ciocchini, A.E., Ugalde, R.A., Iñón de Iannino, N., 2004. Molecular cloning and characterization of $c$ gt, the Brucella abortus cyclic beta-1,2-glucan transporter gene, and its role in virulence. Infect. Immun. 72, 2263-2271.

Sampson, S.L., 2011. Mycobacterial PE/PPE proteins at the host-pathogen interface. Clin. Dev. Immunol. 2011, 497203.

Sebatjane, S.I., Pretorius, A., Liebenberg, J., Steyn, H., Van Kleef, M., 2010. In vitro and in vivo evaluation of five low molecular weight proteins of Ehrlichia ruminantium as potential vaccine components. Vet. Immunol. Immunopathol. 137, 217-225.

Sette, A., Rappuoli, R., 2010. Reverse vaccinology: developing vaccines in the era of genomics. Immunity 33, 530-541.

Smeed, J.A., Watkins, C.A., Rhind, S.M., Hopkins, J., 2007. Differential cytokine gene expression profiles in the three pathological forms of sheep paratuberculosis. BMC Vet. Res. 3, 18.

Sprenger, J., Fink, J.L., Teasdale, R.D., 2006. Evaluation and comparison of mammalian subcellular localization prediction methods. BMC Bioinformatics 7 Suppl 5, S3.

Thacker, T.C., Palmer, M.V., Waters, W.R., 2007. Associations between cytokine gene expression and pathology in Mycobacterium bovis infected cattle. Vet. Immunol. Immunopathol. 119, 204-213.

Totté, P., Vachiery, N., Martinez, D., Trap, I., Ballingall, K.T., MacHugh, N.D., Bensaid, A., Wérenne, J., 1996. Recombinant bovine interferon gamma inhibits the growth of Cowdria ruminantium but fails to induce major histocompatibility complex class II following infection of endothelial cells. Vet. Immunol. Immunopathol. 53, 61-71.

Totté, P., Bensaid, A., Mahan, S.M., Martinez, D., McKeever, D.J., 1999. Immune responses to Cowdria ruminantium infections. Parasitol. Today 15, 286-290. 
Vachiéry, N., Lefrançois, T., Esteves, I., Molia, S., Sheikboudou, C., Kandassamy, Y., Martinez, D., 2006. Optimisation of the inactivated vaccine dose against heartwater and in vitro quantification of Ehrlichia ruminantium challenge material. Vaccine $24,4747-4756$.

Van Kleef, M., Macmillan, H., Gunter, N.J., Zweygarth, E., Allsopp, B.A., Shkap, V., Du Plessis, D.H., Brown, W.C., 2002. Low molecular weight proteins of Cowdria ruminantium (Welgevonden isolate) induce bovine CD4+-enriched T-cells to proliferate and produce interferon-gamma. Vet. Microbiol. 85, 259-273.

Wakeel, A., Zhu, B., Yu, X.J., McBride, J.W., 2010. New insights into molecular Ehrlichia chaffeensis-host interactions. Microbes Infect. 12, 337-345.

Waters, W.R., Palmer, M.V., Thacker, T.C., Davis, W.C., Sreevatsan, S., Coussens, P., Meade, K.G., Hope, J.C., Estes, D.M., 2011. Tuberculosis immunity: opportunities from studies with cattle. Clin. Dev. Immunol. $2011,768542$.

Werling, D., Piercy, J., Coffey, T.J., 2006. Expression of TOLL-like receptors (TLR) by bovine antigen-presenting cells_-Potential role in pathogen discrimination? Vet. Immunol. Immunopathol. 112, $2-11$.

Winder, A.A., Wohlford-Lenane, C., Scheetz, T.E., Nardy, B.N., Manzel, L.J., Look, D.C., McCray, P.B. Jr., 2009. Differential effects of cytokines and corticosteroids on toll-like receptor 2 expression and activity in human airway epithelia. Respir. Res. 10, 96.

Yu, C.S., Lin, C.J., Hwang, J.K., 2004. Predicting subcellular localization of proteins for Gram-negative bacteria by support vector machines based on n-peptide compositions. Protein Sci. 13, 1402-1406.

Yu, N.Y., Wagner, J.R., Laird, M.R., Melli, G., Rey, S., Lo, R., Dao, P., Sahinalp, S.C., Ester, M., Foster, L.J., Brinkman, F.S., 2010. PSORTb 3.0: improved protein subcellular localization prediction with refined localization subcategories and predictive capabilities for all prokaryotes. Bioinformatics 26, 1608-1615. 
Zhu, B., Nethery, K.A., Kuriakose, J.A., Wakeel, A., Zhang, X., McBride, J.W., 2009. Nuclear translocated Ehrlichia chaffeensis ankyrin protein interacts with a specific adenine-rich motif of host promoter and intronic Alu elements. Infect. Immun. 77, 4243-4255. 
Table 1. Number of ORFs identified as possible vaccine candidates grouped according to their putative function.

\begin{tabular}{lcc}
\hline & Round 1 & Round 2 \\
\hline Unknown function & 80 & 70 \\
Unknown, some miscellaneous information & 61 & 23 \\
Membrane-associated & 148 & 98 \\
Exported & 27 & 24 \\
Type IV secretion system & 14 & 9 \\
ABC transporters & 16 & 8 \\
Other transporters & 32 & 12 \\
Proteases & 19 & 12 \\
Chaperones & 13 & 7 \\
Protection responses and adaptation & 4 & 4 \\
Other* & 5 & 5 \\
\hline Total & $\mathbf{4 1 9}$ & $\mathbf{2 7 2}$ \\
\hline \hline
\end{tabular}

* ORFs from other categories shown to be protective or immunogenic in other organisms. 
Table 2. Cytokine profiles induced by recombinant proteins in PBMC from immune sheep or cattle determined by ELISPOT and qPCR assays. The qPCR was done using the same sheep or bovine PBMC that produced IFN- $\gamma$ spot producing cells and were stimulated with protein at the same concentration indicated for the ELISPOT assay.

\begin{tabular}{|c|c|c|c|c|c|c|c|c|c|c|c|c|c|c|c|c|c|c|}
\hline \multirow{5}{*}{$\begin{array}{l}\text { Sheep } \\
\text { PBMC }\end{array}$} & \multirow{5}{*}{$\begin{array}{l}\text { Cytokine } \\
\text { profile A }\end{array}$} & \multirow{2}{*}{$\begin{array}{c}\text { Protein used } \\
\text { to stimulate } \\
\text { PBMC } \\
\text { (Erum ID) }\end{array}$} & \multirow{2}{*}{$\begin{array}{l}\text { Immune sheep/ } \\
\text { bovine number }\end{array}$} & \multirow{2}{*}{$\begin{array}{c}\text { Protein } \\
\text { conc. } \\
(\mu \mathrm{g} / \mathrm{ml})\end{array}$} & \multirow{2}{*}{$\underset{\text { SPMC }}{\text { ELISPOT }^{a}}$} & \multicolumn{13}{|c|}{$\begin{array}{l}\text { qPCR: Cytokine mRNA fold increase } \\
\text { Sheep (overnight) and Bovine: (4h; overnight) }\end{array}$} \\
\hline & & & & & & IFN- $\gamma$ & TNF- $\alpha$ & IL-18 & $\begin{array}{c}\text { IL-12- } \\
\text { p40 }\end{array}$ & $\begin{array}{l}\text { GM- } \\
\text { CSF }\end{array}$ & TLR4 & TLR2 & iNOS & IL-8 & IL-1 $\alpha$ & IL-4 & IL-6 & IL-10 \\
\hline & & Erum Ag & 6050 & 1 & 244 & 469 & $\mathrm{n} / \mathrm{d}$ & $\mathrm{n} / \mathrm{d}$ & $\mathrm{n} / \mathrm{d}$ & $\mathrm{n} / \mathrm{d}$ & $\mathrm{n} / \mathrm{d}$ & $\mathrm{n} / \mathrm{d}$ & $\mathrm{n} / \mathrm{d}$ & $\mathrm{n} / \mathrm{d}$ & $\mathrm{n} / \mathrm{d}$ & - & $\mathrm{n} / \mathrm{d}$ & $\mathrm{n} / \mathrm{d}$ \\
\hline & & Erum5400 & 6050 & 1 & 35 & 31 & 7 & 2 & $\mathrm{n} / \mathrm{d}$ & $\mathrm{n} / \mathrm{d}$ & $\mathrm{n} / \mathrm{d}$ & $\mathrm{n} / \mathrm{d}$ & $\mathrm{n} / \mathrm{d}$ & - & 7 & - & $\mathrm{n} / \mathrm{d}$ & $\mathrm{n} / \mathrm{d}$ \\
\hline & & Erum8050 & 6050 & 1 & 27 & 9 & 7 & 3 & $\mathrm{n} / \mathrm{d}$ & $\mathrm{n} / \mathrm{d}$ & $\mathrm{n} / \mathrm{d}$ & $\mathrm{n} / \mathrm{d}$ & $\mathrm{n} / \mathrm{d}$ & - & 10 & - & $\mathrm{n} / \mathrm{d}$ & $\mathrm{n} / \mathrm{d}$ \\
\hline \multirow{25}{*}{$\begin{array}{l}\text { Bovine } \\
\text { PBMC }\end{array}$} & \multirow{11}{*}{$\begin{array}{l}\text { Cytokine } \\
\text { profile A }\end{array}$} & Erum Ag & 8347 & 1 & 493 & $\mathrm{n} / \mathrm{d}^{\mathrm{c}}$ & $\mathrm{n} / \mathrm{d}$ & $\mathrm{n} / \mathrm{d}$ & - & $\mathrm{n} / \mathrm{d}$ & $\mathrm{n} / \mathrm{d}$ & $\mathrm{n} / \mathrm{d}$ & $\mathrm{n} / \mathrm{d}$ & $\mathrm{n} / \mathrm{d}$ & $\mathrm{n} / \mathrm{d}$ & $\mathrm{n} / \mathrm{d}$ & $\mathrm{n} / \mathrm{d}$ & $\mathrm{n} / \mathrm{d}$ \\
\hline & & Erum Ag & 8404 & 1 & 200 & $2 ; 64$ & $\mathbf{1} ; 10$ & $2 ; 1$ & - & $1 ; 11$ & $1 ; 9$ & $1 ; 4$ & $\mathbf{1} ; 18$ & $1 ; 7$ & $1 ; 16$ & $1 ; 11$ & $1 ; 7$ & $1 ; 9$ \\
\hline & & Erum Ag & 8460 & 1 & 985 & $1 ; 232$ & $2 ; 18$ & $1 ; 3$ & - & $1 ; 9$ & $1 ; 11$ & $-; 12$ & $1 ; 21$ & $-; 21$ & $1 ; 32$ & $1 ; 3$ & $2 ; 48$ & $-; 10$ \\
\hline & & Erum0660_1 & 8460 & 10 & 85 & $3 ; 16$ & $6 ; 10$ & $3 ; 3$ & $4 ; 3$ & $11 ; 58$ & $-; 5$ & $-; 3$ & $6 ; 39$ & $-; 2$ & $4 ; 11$ & . & $2 ; 1$ & $\mathbf{6} ; 4$ \\
\hline & & Erum1 150 & $8347 ; 8404 ; 8460$ & $1 ; 10 ; 1$ & $320 ; 85 ; 77^{\mathrm{b}}$ & $2 ; 8$ & $2 ; 5$ & - & - & $-; 8$ & . & . & - & - & - & - & $-; 18$ & . \\
\hline & & Erum7130 & 8404 & 1 & 5 & $\mathbf{9} ; 13$ & $7 ; 15$ & - & - & $11 ; 7$ & $-; 8$ & - & $24 ; 100$ & $-; 10$ & $4 ; 2$ & . & - & $-; 7$ \\
\hline & & Erum7140 & $8347 ; 8460$ & $1 ; 10$ & $52 ; 27$ & $\mathbf{8} ; 49$ & $-; 2$ & $-; 4$ & - & $-; 13$ & $-; 4$ & - & $14 ; 132$ & $-; 21$ & $-; 13$ & - & . & - \\
\hline & & Erum7280 & 8460 & 0.1 & 48 & $3 ; 246$ & $\mathbf{8} ; 19$ & $-; 10$ & - & $13 ; 11$ & $-; 11$ & - & $24 ; 87$ & - & $-; 4$ & $-; 10$ & - & $5 ; 9$ \\
\hline & & Erum7620 & 8460 & 10 & 20 & $1 ; 809$ & $-; 24$ & - & - & $-; 9$ & $-; 10$ & - & $-; 170$ & - & $-; 4$ & $-; 7$ & - & $-; 11$ \\
\hline & & Erum8010 & 8460 & 0.1 & 42 & $4 ; 33$ & $-; 10$ & $-; 8$ & - & $-; 18$ & $-; 9$ & - & $-; 516$ & $-; 6$ & $-; 5$ & $-; 5$ & - & $-; 7$ \\
\hline & & Erum8460 & 8347 & 0.1 & 52 & $6 ; 42$ & $-; 6$ & $-; 4$ & $-; 10$ & $20 ; 17$ & $-; 3$ & - & $21 ; 76$ & $-; 19$ & $-; 5$ & - & - & $-; 2$ \\
\hline & \multirow{3}{*}{$\begin{array}{l}\text { Cytokine } \\
\text { profile B }\end{array}$} & Erum1040_3 & 8460 & 1 & 37 & $4 ;-^{d}$ & $7 ;-$ & $3 ;-$ & - & $-; 11$ & - & - & $10 ; 2$ & - & $4 ;-$ & - & $4 ;-$ & $5 ;-$ \\
\hline & & Erum1050 & $8347 ; 8404 ; 8460$ & $10 ; 10 ; 1$ & $158 ; 73 ; 20$ & $2 ;-$ & $6 ;-$ & $2 ;-$ & $4 ;-$ & $10 ; 2$ & - & - & $3 ; 4$ & - & $3 ; 2$ & - & - & $3 ;-$ \\
\hline & & Erum8510 & 8460 & 0.1 & 35 & $14 ;-$ & $8 ;-$ & $2 ;-$ & - & $12 ;-$ & $5 ;-$ & - & $16 ; 5$ & - & . & . & - & . \\
\hline & \multirow{7}{*}{$\begin{array}{l}\text { Cytokine } \\
\text { profile C }\end{array}$} & Erum2330 & 8404 & 1 & 0 & $4 ;-$ & - & 4;- & - & $29 ; 3$ & - & - & $-; 5$ & $-; 2$ & - & $-; 2$ & . & . \\
\hline & & Erum4450 & 8460 & 10 & 0 & $3 ; 2$ & - & $118 ; 19$ & - & $7 ; 3$ & - & - & $-; 38$ & $-; 8$ & - & $-; 2$ & - & . \\
\hline & & Erum4530 & 8460 & 10 & 0 & $5 ; 2$ & - & $184 ; 15$ & - & $7 ; 3$ & - & - & $14 ; 26$ & $25 ; 4$ & - & . & . & $5 ; 2$ \\
\hline & & Erum4640 & 8460 & 1 & 0 & $2 ;-$ & - & $11 ;-$ & - & $6 ; 2$ & $4 ;-$ & - & $4 ; 7$ & - & - & $4 ;-$ & - & $-; 12$ \\
\hline & & Erum5420 & 8460 & 1 & 0 & $4 ; 2$ & - & $138 ; 33$ & - & $8 ; 6$ & - & - & $19 ; 10$ & $28 ; 6$ & $-; 3$ & $-; 3$ & . & $-; 2$ \\
\hline & & Erum6200 & 8460 & 10 & 0 & $3 ;-$ & - & $87 ; 8$ & - & $7 ;-$ & - & - & $21 ; 2$ & $16 ;-$ & $-; 3$ & $-; 3$ & - & $-; 2$ \\
\hline & & Erum7110 & 8404 & 1 & 0 & $3 ;-$ & - & $46 ; 5$ & - & $4 ; 2$ & - & - & $18 ; 5$ & $-; 3$ & - & - & - & - \\
\hline & \multirow{4}{*}{$\begin{array}{l}\text { Cytokine } \\
\text { profile D }\end{array}$} & Erum1851 & 8404 & 0.1 & 0 & $3 ;-$ & 9;- & - & - & $12 ;-$ & - & - & $7 ;-$ & - & $4 ;-$ & - & - & - \\
\hline & & Erum1900 & 8404 & 0.1 & 0 & $3 ;-$ & $5 ;-$ & - & - & $7 ;-$ & - & - & $8 ; 3$ & - & $4 ;-$ & - & - & 5 ;- \\
\hline & & Erum2440 & 8460 & 0.1 & 0 & $3 ;-$ & $4 ;-$ & - & . & $16 ;-$ & $4 ;-$ & - & 6;- & - & - & - & - & $2 ;-$ \\
\hline & & Erum 3221 & 8347 & 10 & 0 & $3 ;-$ & . & - & . & $16 ;-$ & . & - & 4;- & $4 ;-$ & $12 ;-$ & . & - & . \\
\hline
\end{tabular}

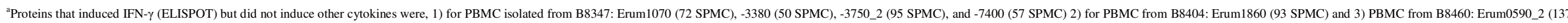

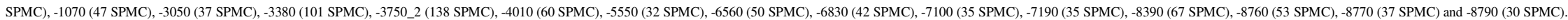

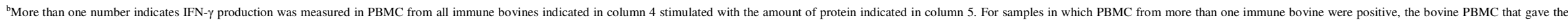
highest ELISPOT value was used in the qPCR, for example for Erum1050 we used bovine 8347 PBMC stimulated with $10 \mathrm{\mu g} / \mathrm{ml}$ protein.

${ }^{c}(\mathrm{n} / \mathrm{d})$ not done.

${ }^{\mathrm{d}}(-)$ value less than 1 fold. 
Table 3. Characteristics of the recombinant proteins, and the ORFS encoding them, inducing cytokine profile A.

\begin{tabular}{|c|c|c|c|c|c|c|c|c|c|}
\hline Erum ID & Predicted protein product & $\begin{array}{l}\text { Length } \\
\text { (aa) }\end{array}$ & $\begin{array}{l}\mathbf{M W}^{\mathrm{a}} \\
(\mathbf{k D a})\end{array}$ & $\begin{array}{c}\text { TMHMM \& } \\
\text { SignalP }^{\mathrm{b}}\end{array}$ & Phobius ${ }^{\mathrm{b}}$ & CELLO $^{c}$ & PSORTb $^{c}$ & Solubility & $\begin{array}{c}\text { Yield } \\
(\mu \mathrm{g} / \mathrm{ml})\end{array}$ \\
\hline Erum5270 & superoxide dismutase $[\mathrm{Fe}]$ & 210 & 24.2 & - & - & extra cellular & unknown & Insoluble & 231 \\
\hline Erum5400 & unknown & 173 & 19.8 & - & 1 th & outer membrane & unknown & Soluble & 369 \\
\hline Erum8050 & exported serine protease & 476 & 51.3 & signal & signal & outer membrane & periplasmic & Soluble & 1015 \\
\hline Erum0660_1 ${ }^{\mathrm{d}}$ & unknown & $422^{\mathrm{d}}$ & 48 & - & - & outer membrane & unknown & Insoluble & 75 \\
\hline Erum1150 & unknown & 179 & 19.5 & - & - & cytoplasmic & cytoplasmic & Soluble & 400 \\
\hline Erum7130 & membrane protein & 186 & 21.1 & 1 th & 1 th & cytoplasmic & cytoplasmic & Soluble & 534 \\
\hline Erum7140 & membrane protein & 197 & 21.9 & 1 th & 1 th & outer membrane & cytoplasmic & Soluble & 209 \\
\hline Erum7280 & membrane protein & 181 & 21.1 & 1 th & 1 th & cytoplasmic & unknown & Insoluble & 233 \\
\hline Erum7620 & integral membrane protein & 120 & 14.4 & 3 th & 3 th & inner membrane & unknown & Insoluble & 133 \\
\hline Erum8010 & integral membrane protein & 118 & 12.3 & 3 th & signal, 2 th & inner membrane & inner membrane & Soluble & 252 \\
\hline Erum8460 & unknown & 56 & 6.4 & - & - & cytoplasmic & cytoplasmic & Soluble & 450 \\
\hline
\end{tabular}

${ }^{a}$ Molecular weight (MW) was predicted using the program Protein Molecular Weight of the Sequence Manipulation Suite (http://www.bioinformatics.org/sms/prot_mw.html).

${ }^{\mathrm{b}}$ The transmembrane helices (th) and signal sequences predicted by TMHMM2.0, SignalP3.0 and Phobius.

${ }^{\mathrm{c}}$ Subcellular localisation predictions by CELLO and pSORTb2.0.

${ }^{\mathrm{d}} 1,266$ bp fragment amplified from the 5' end of a large ORF (11,145 bp encoding 3,715 aa). 


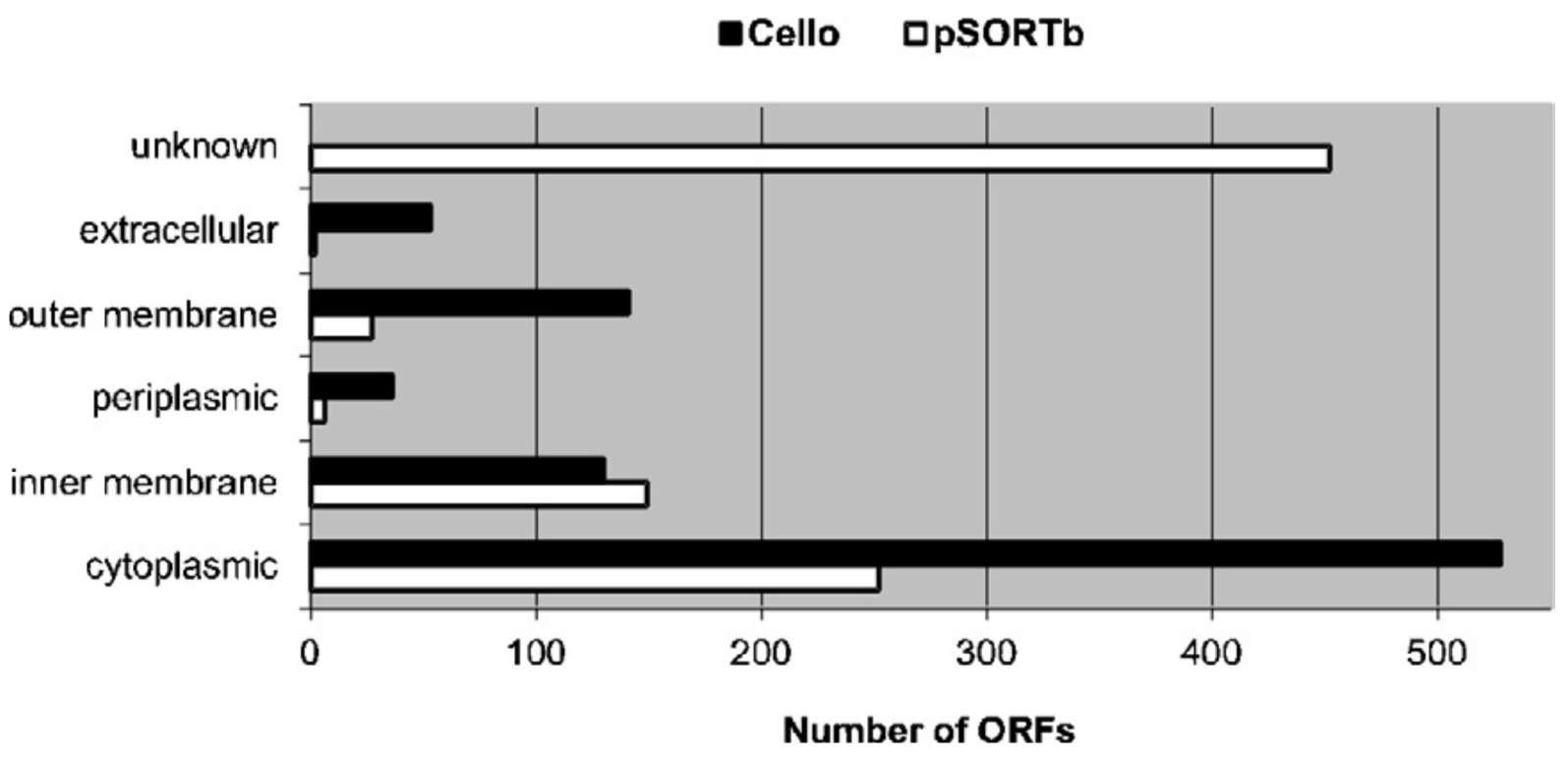

Figure 1. Predicted compartmentalisation of putative proteins by pSORTb and CELLO. 


\section{Supporting information}

Table S1. The 272 selected ORFs grouped according to their putative function (th = transmembrane helices; $\mathrm{C}=$ cytoplasmic, $\mathrm{P}=$ periplasmic, $\mathrm{IM}=$ inner membrane, $\mathrm{OM}=$ outer membrane, $\mathrm{E}=$ extra cellular, $\mathrm{U}=$ unknown; $\mathrm{TR}=$ tandem repeat, $\mathrm{TPR}=$ tetratricopeptide repeat).

\begin{tabular}{|c|c|c|c|c|c|c|c|c|c|c|}
\hline $\begin{array}{l}\text { Erum } \\
\text { ID } \\
\end{array}$ & $\begin{array}{l}\text { gene } \\
\text { name }\end{array}$ & putative protein product & $\begin{array}{c}\text { length } \\
\text { (aa) }\end{array}$ & $\mathrm{pl}^{\mathrm{a}}$ & $\begin{array}{c}M^{a}{ }^{a} \\
(k D a)\end{array}$ & $\begin{array}{l}\text { TMHMM/ } \\
\text { SignalP }\end{array}$ & Phobius & CELLO & pSORTb & repeats $^{b}$ \\
\hline \multicolumn{11}{|c|}{ Type IV secretion system } \\
\hline 0260 & virD4 & type IV secretion system protein VirD4 & 801 & 4.58 & 93.5 & 3 th & 2 th & C & IM & TR \\
\hline 0270 & virB11 & type IV secretion system protein VirB11 & 332 & 6.62 & 36.9 & & & C & $U$ & \\
\hline 0280 & virB10 & type IV secretion system protein VirB10 & 448 & 5.65 & 48.7 & 1 th & 1 th & $\mathrm{P}$ & $U$ & TR \\
\hline 0290 & virB9 & type IV secretion system protein VirB9 & 267 & 8.88 & 31.0 & signal & signal & E & $u$ & \\
\hline 0300 & virB8 & type IV secretion system protein VirB8 & 232 & 9.60 & 26.9 & 1 th & 1 th & OM & $\mathrm{U}$ & \\
\hline 4410 & & type IV secretion system protein & 232 & 5.97 & 27.0 & 1 th & 1 th & OM & OM & \\
\hline 5210 & & type IV secretion system protein & 2455 & 4.35 & 267.7 & 4 th, signal & 6 th, signal & OM & OM & TR \\
\hline 5260 & virB3 & type IV secretion system protein VirB3 & 97 & 9.37 & 11.2 & 2 th & 2 th & IM & $u$ & \\
\hline 7980 & & type IV secretion system protein & 790 & 5.90 & 90.2 & & & C & C & \\
\hline \multicolumn{11}{|c|}{$A B C$ transporters } \\
\hline 0580 & & $\mathrm{ABC}$ transporter, ATP binding protein & 239 & 8.66 & 26.4 & & & C & $\mathrm{U}$ & \\
\hline 0860 & IOIE & lipoprotein releasing system transmembrane protein LolE & 411 & 7.00 & 45.5 & 4 th & 4 th & IM & IM & \\
\hline 1190 & IOID & lipoprotein releasing system ATP-binding protein LoID & 228 & 9.10 & 25.1 & & signal & C & IM & \\
\hline 3110 & $u v r A$ & uvrABC system protein $A$ ( $A B C$ transporter domain, ATP/GTP-binding) & 959 & 8.62 & 107.2 & & & OM & OM & \\
\hline 5760 & pstB & phosphate $A B C$ transporter, ATP-binding protein & 253 & 9.02 & 28.5 & & & C & $\mathrm{U}$ & \\
\hline 6270 & & ABC transporter, ATP-binding protein & 593 & 9.33 & 64.6 & 5 th & 5 th & IM & IM & \\
\hline 6820 & & $A B C$ transporter, ATP-binding and membrane-spanning protein & 583 & 8.98 & 63.9 & 5 th & 6 th & OM & IM & \\
\hline 7050 & $\operatorname{ccm} A$ & heme exporter protein $\mathrm{A}$ & 213 & 7.64 & 24.5 & & & $\mathrm{C}$ & $U$ & \\
\hline \multicolumn{11}{|c|}{ Other transporters } \\
\hline 0190 & $\operatorname{corC}$ & magnesium and cobalt efflux protein & 288 & 4.96 & 32.6 & & 1 th & C & C & \\
\hline 1170 & $\sec G$ & protein-export membrane protein SecG & 110 & 5.39 & 12.0 & 2 th & 1 th, signal & $\mathrm{P} / \mathrm{IM}$ & $u$ & \\
\hline 1590 & & secretion protein & 514 & 9.37 & 57.8 & 1 th & 2 th & OM & IM & \\
\hline 1780 & & $\mathrm{Na}+/ \mathrm{H}+$ antiporter subunit & 172 & 9.68 & 19.5 & 2 th & 2 th & IM & IM & \\
\hline 2560 & tatA & Sec-independent protein translocase membrane protein & 56 & 5.04 & 6.2 & 1 th & 1 th & C & $U$ & \\
\hline 4600 & & magnesium transporter & 456 & 5.6 & 51.2 & 4 th & 5 th & IM & IM & \\
\hline 5430 & $f f h$ & signal recognition particle protein (GTPase) & 450 & 9.40 & 49.6 & & & $\mathrm{C}$ & $\mathrm{C}$ & \\
\hline
\end{tabular}




\begin{tabular}{|c|c|c|c|c|c|c|c|c|c|}
\hline 5530 & & $\mathrm{Na}+/ \mathrm{H}+$ antiporter subunit & 139 & 5.16 & 15.0 & 4 th & 4 th & IM & $\mathrm{IM}$ \\
\hline 5550 & & $\mathrm{Na}+/ \mathrm{H}+$ antiporter subunit & 99 & 7.8 & 10.8 & 3 th & 3 th & IM & IM \\
\hline 7780 & & preprotein translocase subunit YajC & 122 & 9.07 & 13.0 & 1 th & 1 th , signal & C & $U$ \\
\hline 7800 & & outer membrane efflux protein & 415 & 6.52 & 45.9 & signal & signal & $\mathrm{OM}$ & $\mathrm{OM}$ \\
\hline 8780 & $\sec A$ & preprotein translocase SecA subunit & 870 & 6.46 & 99.9 & & & C & C \\
\hline \multicolumn{10}{|c|}{ Chaperones } \\
\hline 0130 & dnaJ & chaperone protein DnaJ & 382 & 8.81 & 42.2 & & & OM & C \\
\hline 1990 & tig & trigger factor & 446 & 5.26 & 50.8 & & & C & $U$ \\
\hline 3500 & ppiD & peptidyl-prolyl cis-trans isomerase D & 630 & 6.39 & 71.8 & 1 th & signal & OM & $\mathrm{OM}$ \\
\hline 4010 & $p m b A$ & PmbA protein & 455 & 5.78 & 49.5 & & & OM & $\mathrm{C}$ \\
\hline 4190 & $h s c A$ & chaperone protein HscA & 616 & 5.94 & 68.8 & & & $\mathrm{C}$ & $\mathrm{C}$ \\
\hline 5500 & $d n a K$ & chaperone protein DnaK & 645 & 5.17 & 69.9 & & & $\mathrm{C}$ & $U$ \\
\hline 7430 & $\sec B$ & protein-export protein SecB & 174 & 4.53 & 19.4 & & & $\mathrm{C}$ & $U$ \\
\hline \multicolumn{10}{|c|}{ Protection responses and adaptation } \\
\hline 3050 & surE & acid phosphatase SurE & 252 & 6.16 & 27.6 & & & $\mathrm{E}$ & $U$ \\
\hline 3350 & cutA & periplasmic divalent cation tolerance protein CutA & 109 & 5.02 & 12.8 & & & $\mathrm{C}$ & $\mathrm{C}$ \\
\hline 3480 & & peroxiredoxin & 205 & 5.84 & 23.3 & & & $\mathrm{C}$ & $\mathrm{C}$ \\
\hline 5270 & $\operatorname{sod} B$ & superoxide dismutase $[\mathrm{Fe}]$ & 210 & 5.53 & 24.2 & & & $E$ & $U$ \\
\hline \multicolumn{10}{|c|}{ Proteases/peptidases } \\
\hline 3510 & & glycoprotease & 193 & 9.06 & 21.5 & & & $\mathrm{C}$ & $U$ \\
\hline 4660 & $c l p A$ & ATP-dependent Clp protease, ATP-binding subunit & 764 & 6.13 & 85.8 & & & $\mathrm{C}$ & $\mathrm{C}$ \\
\hline 5610 & & carboxypeptidase & 491 & 6.83 & 56.7 & & & C & $U$ \\
\hline 6130 & & peptidase & 289 & 8.45 & 32.3 & 1 th & 1 th & $\mathrm{OM}$ & $U$ \\
\hline 7410 & & zinc protease & 421 & 5.28 & 47.9 & & & E & $U$ \\
\hline 8050 & & exported serine protease & 476 & 8.35 & 51.3 & signal & signal & OM & $\mathrm{P}$ \\
\hline 8090 & & exported peptidase & 438 & 5.08 & 49.8 & signal & signal & C & $\mathrm{P}$ \\
\hline 8100 & & exported M16 family peptidase & 455 & 4.90 & 51.4 & signal & signal & $\mathrm{E} / \mathrm{OM}$ & $U$ \\
\hline 8120 & IpsA & lipoprotein signal peptidase & 149 & 9.10 & 17.2 & 3 th & 4 th & IM & $\mathrm{IM}$ \\
\hline 8220 & & exported D-alanyl-D-alanine carboxypeptidase & 290 & 5.46 & 32.8 & signal & signal & IM & $U$ \\
\hline 8250 & & membrane-associated zinc metalloprotease & 379 & 9 & 42.2 & 4 th & 4 th & IM & IM \\
\hline 8430 & $f t s H$ & cell division protein FtsH (ATP-dependent zinc metallopeptidase) & 611 & 7.24 & 67.6 & 2 th & 1 th, signal & IM & IM \\
\hline \multicolumn{10}{|c|}{ Unknown with some miscellaneous information } \\
\hline 0050 & & unknown & 101 & 6.72 & 11.5 & & & $\mathrm{C}$ & $\mathrm{U}$ \\
\hline 0320 & & unknown (TPR domain) & 354 & 9.38 & 41.0 & & & C & $U$ \\
\hline 1300 & & unknown (zinc metallopeptidases, zinc-binding region signature) & 1334 & 5.37 & 153.1 & & & E & $\mathrm{OM}$ \\
\hline 1840 & & unknown (patatin-like) & 267 & 5.61 & 30.1 & & & C & $\mathrm{U}$ \\
\hline 2690 & & unknown & 352 & 8.43 & 38.5 & & & $\mathrm{E}$ & $\mathrm{U}$ \\
\hline
\end{tabular}

TPR 


\begin{tabular}{|c|c|c|c|c|c|c|c|c|c|c|}
\hline 2980 & & unknown & 186 & 9.49 & 21.3 & & & $E$ & $u$ & \\
\hline 3700 & typA & GTP-binding protein TypA/BipA (GTPase) & 612 & 5.42 & 67.4 & & & C & C & \\
\hline 3730 & & unknown & 153 & 3.92 & 17 & & & C & $U$ & \\
\hline 3750 & & unknown (Ankyrin repeats) & 1674 & 5.09 & 179.8 & & & $\mathrm{OM}$ & C & Ankyrin \\
\hline 3980 & & unknown (Ankyrin repeats) & 3002 & 5.82 & 330.3 & & & $\mathrm{OM}$ & $\mathrm{E}$ & Ankyrin, TR \\
\hline 4950 & & competence protein & 492 & 9.19 & 54.1 & & & $\mathrm{C}$ & C & \\
\hline 5120 & & secretion protein & 363 & 6.02 & 40.68 & 1 th & 1 th & $\mathrm{OM}$ & $u$ & \\
\hline 5400 & & unknown & 173 & 8.92 & 19.8 & & 1 th & $\mathrm{OM}$ & $U$ & \\
\hline 5420 & era & GTP-binding protein ERA (GTPase) & 296 & 9.08 & 33.7 & & & $\mathrm{C}$ & $u$ & \\
\hline 5620 & & unknown (OmpA or pal) & 217 & 6.08 & 24.4 & & signal & $P$ & $\mathrm{OM}$ & \\
\hline 6220 & & unknown (Ankyrin repeats) & 125 & 5.76 & 14.2 & & & C & $u$ & Ankyrin \\
\hline 6540 & & zinc metallopeptidase & 433 & 6.03 & 49.8 & 2 th & signal & $\mathrm{IM}$ & $\mathrm{IM}$ & \\
\hline 6670 & & haloacid dehalogenase-like hydrolase & 210 & 5.7 & 23.5 & & & $\mathrm{E}$ & $\mathrm{U}$ & \\
\hline 6970 & & unknown & 95 & 8.87 & 11.0 & & & C & C & \\
\hline 7850 & & unknown & 209 & 8.41 & 23.4 & & & C & $\mathrm{U}$ & \\
\hline 7960 & & unknown & 1304 & 7.70 & 150.1 & & signal & $\mathrm{OM}$ & $\mathrm{OM}$ & \\
\hline 8150 & & methyltransferase & 280 & 9.19 & 32.3 & & & C & $u$ & \\
\hline 8240 & & conserved hypothetical protein (TPR repeat region) & 93 & 6.28 & 11.1 & & & C & C & TPR \\
\hline \multicolumn{11}{|c|}{ Membrane and surface-associated } \\
\hline 0090 & & membrane protein & 193 & 9.66 & 23.0 & 1 th, signal & 2 th & $P$ & $u$ & \\
\hline 0330 & & integral membrane protein & 159 & 8.55 & 18.7 & 2 th & 2 th & C & C & \\
\hline 0590 & & integral membrane protein & 613 & 8.73 & 70.7 & 3 th & 3 th & $\mathrm{OM}$ & $U$ & \\
\hline 0700 & & integral membrane protein & 547 & 9.11 & 61.4 & 2 th & 2 th, signal & $\mathrm{OM}$ & $u$ & \\
\hline 0831 & & integral membrane protein & 84 & 4.72 & 9.6 & 2 th & 2 th & $\mathrm{IM}$ & $U$ & \\
\hline 0840 & & integral membrane protein & 413 & 8.62 & 49.2 & 2 th & 1 th, signal & C & C & \\
\hline 0850 & & membrane protein (lipoprotein lipid attachment site) & 258 & 6.96 & 30.1 & 1 th & 1 th & C & C & \\
\hline 0970 & & integral membrane protein & 155 & 9.00 & 18.3 & 4 th & 4 th & $\mathrm{IM}$ & $\mathrm{IM}$ & \\
\hline 0990 & & integral membrane protein & 607 & 6.15 & 68.6 & 2 th & 2 th & $\mathrm{OM}$ & $\mathrm{OM}$ & \\
\hline 1040 & & integral membrane protein & 1165 & 4.63 & 128.8 & 2 th & 2 th & E & C & TR \\
\hline 1050 & & integral membrane protein & 454 & 6.54 & 51.6 & 2 th & 2 th & $\mathrm{OM}$ & $\mathrm{U}$ & \\
\hline 1440 & & membrane protein & 482 & 6.28 & 55.0 & 1 th & 1 th & C & $\mathrm{IM}$ & \\
\hline 1450 & & membrane protein & 208 & 8.94 & 23.7 & 1 th & 1 th & $\mathrm{OM}$ & $\mathrm{U}$ & \\
\hline 1620 & & integral membrane protein & 197 & 8.47 & 22.1 & 4 th & 4 th & $\mathrm{IM}$ & $\mathrm{IM}$ & \\
\hline 1750 & & integral membrane protein & 142 & 9.15 & 16.1 & 4 th & 4 th & $\mathrm{IM}$ & $\mathrm{IM}$ & \\
\hline 1790 & & membrane protein & 205 & 8.28 & 23.4 & 1 th & 1 th & C & $u$ & \\
\hline 1860 & & membrane protein & 270 & 8.47 & 31.3 & 1 th & signal & C & $u$ & \\
\hline 2070 & & integral membrane protein & 431 & 6.12 & 48.1 & 4 th & 2 th, signal & $\mathrm{IM}$ & $\mathrm{IM}$ & \\
\hline
\end{tabular}




$\begin{array}{ll}2080 & \text { integral membrane protein } \\ 2180 & \text { integral membrane protein (Ankyrin repeats) } \\ 2240 & \text { membrane protein } \\ 2250 & \text { membrane protein } \\ 2260 & \text { membrane protein } \\ 2270 & \text { membrane protein } \\ 2280 & \text { membrane protein } \\ 2290 & \text { membrane protein } \\ 2300 & \text { membrane protein } \\ 2330 & \text { membrane protein } \\ 2340 & \text { membrane protein } \\ 2400 & \text { membrane protein } \\ 2410 & \text { membrane protein } \\ 2440 & \text { integral membrane protein } \\ 2470 & \text { integral membrane protein } \\ 2750 & \text { membrane protein } \\ 2760 & \text { membrane protein } \\ 2770 & \text { membrane protein } \\ 2780 & \text { membrane protein } \\ 2790 & \text { integral membrane protein } \\ 2800 & \text { membrane protein } \\ 2900 & \text { integral membrane protein } \\ 3240 & \text { integral membrane protein } \\ 3570 & \text { integral membrane protein } \\ 3580 & \text { integral membrane protein } \\ 3590 & \text { integral membrane protein } \\ 3600 & \text { integral membrane protein } \\ 3610 & \text { membrane protein } \\ 3620 & \text { integral membrane protein } \\ 3630 & \text { membrane protein } \\ 3860 & \text { membrane protein } \\ 4070 & \text { integral membrane protein } \\ 4210 & \text { membrane protein } \\ 4230 & \\ 4440 & \text { integral membrane protein } \\ 4610 & \text { metein protein } \\ 4620 & \end{array}$

\begin{tabular}{|c|c|c|c|c|c|c|c|}
\hline 94 & 9.45 & 11.2 & 2 th & 3 th & IM & U & \\
\hline 876 & 6.24 & 98.8 & 2 th & 2 th & $\mathrm{OM}$ & C & Ankyrin \\
\hline 369 & 9.17 & 42.5 & 1 th & 1 th & C & $U$ & \\
\hline 347 & 8.45 & 39.6 & 1 th & 1 th & $\mathrm{IM}$ & $U$ & \\
\hline 313 & 7.70 & 35.9 & 1 th & 1 th & E & U & \\
\hline 384 & 9.54 & 44.5 & 1 th & 1 th & E & U & \\
\hline 341 & 9.56 & 39.3 & 1 th & 1 th & C & U & \\
\hline 342 & 9.14 & 39.6 & 1 th & 1 th & $E / C$ & U & \\
\hline 370 & 8.99 & 43.6 & 1 th & 1 th & C & $U$ & \\
\hline 306 & 8.62 & 34.9 & 1 th & 1 th & $\mathrm{IM}$ & U & \\
\hline 326 & 8.22 & 37.4 & 1 th & 1 th & C & U & \\
\hline 391 & 5.32 & 44.8 & 1 th & 1 th & $E$ & U & TR \\
\hline 326 & 5.56 & 37.1 & 1 th & 1 th & C & U & \\
\hline 220 & 5.09 & 25.0 & 2 th & 2 th & IM & U & \\
\hline 358 & 8.22 & 41.6 & 2 th & 4 th & C & $\mathrm{IM}$ & \\
\hline 527 & 6.57 & 60.8 & 1 th, signal & 2 th & E & $\mathrm{IM}$ & \\
\hline 519 & 9.09 & 60.2 & 1 th, signal & 2 th & OM & $\mathrm{U}$ & \\
\hline 526 & 8.6 & 60.4 & 1 th, signal & 2 th & C & $U$ & \\
\hline 524 & 7.06 & 59.9 & 1 th, signal & 2 th & C & $U$ & \\
\hline 653 & 5.82 & 75.3 & 2 th & 2 th & C & OM & \\
\hline 520 & 6.4 & 60.9 & 1 th, signal & 2 th & C & U & TR \\
\hline 331 & 5.96 & 37.5 & 2 th & 2 th & $\mathrm{C}$ & C & \\
\hline 210 & 9.84 & 23.2 & 4 th & 4 th & IM & IM & \\
\hline 376 & 5.45 & 40.9 & 2 th & 2 th & E & U & TR \\
\hline 188 & 6.83 & 21.3 & 2 th & signal, 1 th & $\mathrm{OM}$ & $U$ & \\
\hline 389 & 4.43 & 41.3 & 2 th & 2 th & E & $\mathrm{U}$ & TR \\
\hline 585 & 5.87 & 67.2 & 2 th & 2 th & $\mathrm{OM}$ & $\mathrm{IM}$ & TR \\
\hline 513 & 5.94 & 59.5 & 1 th, signal & 2 th & C & $U$ & \\
\hline 537 & 8.92 & 60.6 & 2 th & 2 th & $\mathrm{OM}$ & U & \\
\hline 519 & 8.67 & 59.1 & 1 th, signal & signal, 1 th & $\mathrm{OM}$ & U & \\
\hline 171 & 8.19 & 20.1 & 1 th & 1 th & E & U & \\
\hline 193 & 9.7 & 22.7 & 3 th & 3 th & $\mathrm{IM}$ & $\mathrm{IM}$ & \\
\hline 356 & 8.67 & 40.4 & 1 th & signal & OM & $U$ & \\
\hline 135 & 9.37 & 15.7 & 2 th & signal & C & $U$ & \\
\hline 195 & 8.78 & 22.4 & 4 th & 4 th & C & $\mathrm{IM}$ & \\
\hline 124 & 6.49 & 14.4 & 1 th & 1 th & C & C & \\
\hline 134 & 5.27 & 15.1 & 1 th & 1 th & IM & $U$ & \\
\hline
\end{tabular}




\begin{tabular}{|c|c|}
\hline 4630 & membrane protein \\
\hline 4640 & membrane protein \\
\hline 4960 & integral membrane protein \\
\hline 5310 & integral membrane protein \\
\hline 5470 & membrane protein \\
\hline 5480 & membrane protein \\
\hline 5520 & integral membrane protein \\
\hline 5560 & integral membrane protein \\
\hline 5700 & membrane protein \\
\hline 6210 & integral membrane protein \\
\hline 6240 & membrane protein \\
\hline 6300 & integral membrane protein \\
\hline 6680 & integral membrane protein \\
\hline 6880 & integral membrane protein \\
\hline 7090 & membrane protein \\
\hline 7100 & membrane protein \\
\hline 7130 & membrane protein \\
\hline 7140 & membrane protein \\
\hline 7250 & membrane protein \\
\hline 7270 & membrane protein \\
\hline 7280 & membrane protein \\
\hline 7300 & integral membrane protein \\
\hline 7310 & integral membrane protein \\
\hline 7320 & integral membrane protein \\
\hline 7330 & membrane protein \\
\hline 7340 & membrane protein \\
\hline 7350 & membrane protein \\
\hline 7360 & membrane protein \\
\hline 7370 & integral membrane protein \\
\hline 7380 & membrane protein \\
\hline 7600 & membrane protein \\
\hline 7620 & integral membrane protein \\
\hline 7950 & ATP/GTP-binding membrane protein \\
\hline 8000 & integral membrane protein \\
\hline 8010 & integral membrane protein \\
\hline 8020 & integral membrane protein \\
\hline 8040 & HfIC membrane protein \\
\hline
\end{tabular}

$\begin{array}{ccccccc}125 & 8.43 & 14.2 & 1 \text { th } & 1 \text { th } & \mathrm{P} & \mathrm{U} \\ 123 & 7.61 & 13.8 & 1 \text { th } & 1 \text { th } & \mathrm{P} & \mathrm{U} \\ 129 & 8.54 & 13.7 & 2 \text { th } & 2 \text { th } & \mathrm{P} / \mathrm{IM} & \mathrm{U} \\ 1392 & 7.83 & 162.9 & 2 \text { th } & 3 \text { th } & \mathrm{C} & \mathrm{C} \\ 158 & 8.95 & 18.3 & 1 \text { th } & 1 \text { th } & \mathrm{C} & \mathrm{U} \\ 111 & 4.64 & 11.8 & 1 \text { th } & \text { signal } & \mathrm{C} & \mathrm{IM} \\ 111 & 9.87 & 12.3 & 3 \text { th } & 3 \text { th } & \mathrm{IM} & \mathrm{IM} \\ 88 & 5.45 & 9.7 & 3 \text { th } & 2 \text { th, signal } & \mathrm{IM} & \mathrm{IM} \\ 142 & 8.87 & 16.9 & 1 \text { th } & 1 \text { th } & \mathrm{C} & \mathrm{U} \\ 285 & 5.84 & 31.9 & 3 \text { th } & 3 \text { th } & \mathrm{IM} & \mathrm{IM} \\ 81 & 4.74 & 9.1 & 1 \text { th } & \text { signal } & \mathrm{P} & \mathrm{U} \\ 352 & 8.61 & 40.3 & 2 \text { th } & 2 \text { th } & \mathrm{C} & \mathrm{U} \\ 170 & 8.68 & 19.7 & 3 \text { th } & 3 \text { th } & \mathrm{IM} & \mathrm{IM} \\ 203 & 4.97 & 23.1 & 3 \text { th } & 3 \text { th } & \mathrm{IM} & \mathrm{IM} \\ 228 & 5.37 & 26.0 & 1 \text { th } & 1 \text { th } & \mathrm{C} & \mathrm{C} \\ 250 & 6.49 & 28.3 & 1 \text { th } & 1 \text { th } & \mathrm{C} & \mathrm{U} \\ 186 & 5.57 & 21.1 & 1 \text { th } & 1 \text { th } & \mathrm{C} & \mathrm{C} \\ 197 & 4.38 & 21.9 & 1 \text { th } & 1 \text { th } & \mathrm{OM} & \mathrm{C} \\ 999 & 6.14 & 113.1 & 1 \text { th } & 1 \text { th } & \mathrm{OM} & \mathrm{OM} \\ 198 & 8.54 & 22.6 & 1 \text { th } & 1 \text { th } & \mathrm{P} & \mathrm{U} \\ 181 & 4.55 & 21.1 & 1 \text { th } & 1 \text { th } & \mathrm{C} & \mathrm{U} \\ 157 & 4.24 & 16.4 & 2 \text { th } & \text { signal, } 1 \text { th } & \mathrm{E} & \mathrm{U} \\ 202 & 4.20 & 22.1 & 2 \text { th } & \text { signal, } 1 \text { th } & \mathrm{E} & \mathrm{U} \\ 266 & 3.97 & 28.1 & 2 \text { th } & 1 \text { th } & \mathrm{OM} & \mathrm{U} \\ 291 & 4.30 & 31.8 & 1 \text { th } & \text { signal, } 1 \text { th } & \mathrm{OM} & \mathrm{U} \\ 122 & 5.35 & 13.3 & 1 \text { th } & 1 \text { th } & \mathrm{C} & \mathrm{U} \\ 145 & 4.90 & 16.2 & 1 \text { th } & 1 \text { th } & \mathrm{E} & \mathrm{U} \\ 147 & 4.62 & 16.1 & 1 \text { th } & 1 \text { th } & \mathrm{IM} & \mathrm{U} \\ 169 & 4.26 & 18.5 & 2 \text { th } & 2 \text { th } & \mathrm{E} & \mathrm{U} \\ 157 & 4.16 & 17.2 & 1 \text { th } & 1 \text { th } & \mathrm{C} & \mathrm{C} \\ 425 & 5.54 & 48.5 & 1 \text { th } & \text { signal } & \mathrm{OM} & \mathrm{U} \\ 120 & 9.4 & 14.4 & 3 \text { th } & 3 \text { th } & \mathrm{IM} & \mathrm{U} \\ 735 & 7.02 & 85.4 & 1 \text { th } & 1 \text { th } & \mathrm{OM} & \mathrm{U} \\ 112 & 8.74 & 11.9 & 3 \text { th } & \text { signal, } 2 \text { th } & \mathrm{IM} & \mathrm{IM} \\ 118 & 9.18 & 12.3 & 3 \text { th } & \text { signal, } 2 \text { th } & \mathrm{IM} & \mathrm{IM} \\ 290 & 8.8 & 13.2 & 3 \text { th } & \text { signal, } 2 \text { th } & \mathrm{IM} & \mathrm{IM} \\ & 9.44 & 33.1 & 1 \text { th } & 1 \text { th } & \mathrm{C} & \mathrm{U}\end{array}$




$\begin{array}{ll}8110 & \text { integral membrane protein } \\ 8260 & \text { outer membrane protein } \\ 8270 & \text { outer membrane protein } \\ 8320 & \text { Surf1-like protein } \\ 8390 & \text { membrane protein } \\ 8510 & \text { membrane protein }\end{array}$

\section{Exported proteins}

\begin{tabular}{ll}
0470 & exported protein \\
1070 & exported protein \\
1210 & exported protein \\
1460 & exported protein \\
1960 & exported protein \\
2310 & exported protein \\
2320 & exported protein \\
3450 & exported protein \\
3780 & exported protein \\
3790 & exported protein \\
4470 & exported protein \\
4740 & exported protein \\
5000 & exported protein \\
5010 & exported protein \\
5140 & exported protein \\
5370 & exported protein \\
6230 & exported protein \\
6650 & exported protein \\
7110 & exported protein \\
7120 & exported protein \\
7760 & exported lipoprotein \\
7970 & exported protein \\
8060 & exported protein \\
8610 & exported protein \\
\hline 14 &
\end{tabular}

\section{Unknown}

$\begin{array}{ll}0250 & \text { unknown } \\ 0350 & \text { unknown } \\ 0500 & \text { unknown } \\ 0660 & \text { unknown } \\ 0680 & \text { unknown }\end{array}$

\begin{tabular}{|c|c|c|c|c|c|c|}
\hline 224 & 8.03 & 24.6 & 4 th & 4 th & IM & $\mathrm{IM}$ \\
\hline 771 & 8.03 & 87.3 & signal & signal & OM & $\mathrm{OM}$ \\
\hline 182 & 6.01 & 21.0 & signal & signal & C & $U$ \\
\hline 213 & 8.9 & 25.1 & 2 th & 2 th & IM & $\mathrm{IM}$ \\
\hline 163 & 6.53 & 18.3 & 1 th & 1 th & C & $C$ \\
\hline 223 & 6.29 & 25.2 & 1 th & & C & $U$ \\
\hline 208 & 8.65 & 24.6 & signal & signal & C & $C$ \\
\hline 180 & 8.99 & 20.9 & signal & 1 th & C & $\mathrm{U}$ \\
\hline 877 & 5.71 & 97.1 & signal & signal & OM & OM \\
\hline 180 & 5.36 & 20.8 & signal & signal & $C$ & $C$ \\
\hline 383 & 6.14 & 45.4 & signal & signal & $\mathrm{OM} / \mathrm{C}$ & $U$ \\
\hline 317 & 6.56 & 36.0 & signal & 1 th & C & $C$ \\
\hline 307 & 8.69 & 35.0 & signal & 1 th & C & $U$ \\
\hline 327 & 6.1 & 36.7 & signal & signal & C & $U$ \\
\hline 223 & 8.73 & 25.4 & signal & signal & $\mathrm{OM}$ & $\mathrm{IM}$ \\
\hline 235 & 6.29 & 27.2 & signal & signal & $\mathrm{OM}$ & OM \\
\hline 385 & 6.10 & 41.8 & signal & signal & OM & OM \\
\hline 639 & 7.61 & 71.9 & signal & signal & E & OM \\
\hline 490 & 8.36 & 53.6 & signal & signal & $\mathrm{OM}$ & OM \\
\hline 564 & 8.50 & 63.0 & signal & signal & OM & OM \\
\hline 389 & 5.82 & 43.4 & signal & signal & OM & $U$ \\
\hline 325 & 5.92 & 37.0 & signal & signal & C & $U$ \\
\hline 134 & 4.16 & 15.6 & signal & signal & $P$ & $U$ \\
\hline 200 & 9.62 & 22.0 & signal & signal & IM & $P$ \\
\hline 182 & 6.88 & 21.5 & signal & 1 th & $C$ & $U$ \\
\hline 204 & 5.33 & 23.3 & signal & 1 th & C & $C$ \\
\hline 250 & 6.15 & 29.3 & signal & signal & C & $\mathrm{U}$ \\
\hline 1710 & 6.38 & 196.7 & signal & signal & $\mathrm{OM}$ & OM \\
\hline 204 & 5.92 & 23.5 & signal & signal & OM & $U$ \\
\hline 236 & 9.70 & 27.8 & signal & signal & OM & $U$ \\
\hline 457 & 4.89 & 50.5 & & & C & $C$ \\
\hline 143 & 9.38 & 16.5 & & & $C$ & U \\
\hline 102 & 8.75 & 11.8 & & & $C$ & $U$ \\
\hline 3715 & 5.35 & 420.2 & & & OM & $U$ \\
\hline 540 & 5.53 & 60.7 & & & OM & $U$ \\
\hline
\end{tabular}




\begin{tabular}{|c|c|}
\hline 0690 & unknown \\
\hline 0710 & unknown \\
\hline 0720 & unknown \\
\hline 0730 & unknown \\
\hline 1110 & unknown \\
\hline 1150 & unknown \\
\hline 1430 & unknown \\
\hline 1600 & unknown \\
\hline 1770 & unknown \\
\hline 1851 & unknown \\
\hline 1900 & unknown \\
\hline 2170 & unknown \\
\hline 2370 & unknown \\
\hline 2380 & unknown \\
\hline 2630 & unknown \\
\hline 2730 & unknown \\
\hline 3221 & unknown \\
\hline 3290 & unknown \\
\hline 3380 & unknown \\
\hline 3410 & unknown \\
\hline 3640 & unknown \\
\hline 3701 & unknown \\
\hline 3890 & unknown \\
\hline 3900 & unknown \\
\hline 3910 & unknown \\
\hline 3920 & unknown \\
\hline 3930 & unknown \\
\hline 3940 & unknown \\
\hline 4261 & unknown \\
\hline 4320 & unknown \\
\hline 4340 & unknown \\
\hline 4350 & unknown \\
\hline 4360 & unknown \\
\hline 4390 & unknown \\
\hline 4400 & unknown \\
\hline 4450 & unknown \\
\hline 4530 & unknown \\
\hline
\end{tabular}

$\begin{array}{ccc}470 & 8.07 & 54.8 \\ 123 & 4.55 & 14.0 \\ 931 & 7.73 & 105.6 \\ 93 & 5.41 & 10.6 \\ 661 & 3.97 & 63.5 \\ 179 & 3.54 & 19.5 \\ 951 & 9.13 & 106.7 \\ 204 & 6.08 & 23.9 \\ 1529 & 6.53 & 170.8 \\ 92 & 7.07 & 10.8 \\ 417 & 9.34 & 44.9 \\ 1073 & 5.89 & 121.8 \\ 417 & 6.56 & 46.9 \\ 332 & 6.11 & 37.6 \\ 1202 & 6.54 & 139.6 \\ 912 & 5.97 & 106.1 \\ 93 & 8.59 & 10.8 \\ 194 & 8.43 & 22.3 \\ 94 & 9.7 & 11.4 \\ 119 & 6.72 & 14.2 \\ 111 & 9.72 & 12.4 \\ 106 & 8.98 & 12.7 \\ 126 & 10.64 & 14.7 \\ 189 & 9.52 & 21.9 \\ 129 & 7.77 & 15.2 \\ 136 & 9.04 & 15.7 \\ 188 & 6.16 & 22.0 \\ 115 & 5.3 & 13.6 \\ 84 & 9.81 & 9.3 \\ 425 & 6.03 & 48.9 \\ 392 & 5.79 & 44.8 \\ 409 & 5.44 & 47.1 \\ 157 & 9.68 & 17.5 \\ 240 & 8.5 & 28.1 \\ 994 & 5.62 & 112.7 \\ 280 & 8.3 & 31.4 \\ 199 & 8.97 & 23.0\end{array}$

\begin{tabular}{|c|c|c|c|}
\hline 1 th & OM & $U$ & \\
\hline signal & C & $U$ & \\
\hline \multirow[t]{4}{*}{1 th, signal } & OM & U & \\
\hline & C & $U$ & \\
\hline & E & $C$ & TR \\
\hline & C & $C$ & \\
\hline \multirow[t]{7}{*}{1 th } & OM & U & TR \\
\hline & C & $U$ & \\
\hline & OM & OM & \\
\hline & C & $C$ & \\
\hline & OM & $U$ & \\
\hline & E & OM & TR \\
\hline & E & U & \\
\hline \multirow[t]{24}{*}{ signal } & OM & U & \\
\hline & $\mathrm{OM} / \mathrm{E}$ & OM & TR \\
\hline & OM & $C$ & \\
\hline & $\mathrm{C}$ & $U$ & \\
\hline & $E$ & $U$ & \\
\hline & C & $U$ & \\
\hline & C & $U$ & \\
\hline & C & $U$ & \\
\hline & C & $U$ & \\
\hline & $\mathrm{P}$ & U & \\
\hline & C & $U$ & \\
\hline & C & $U$ & \\
\hline & C & $U$ & \\
\hline & C & $C$ & \\
\hline & C & $C$ & \\
\hline & $P$ & U & \\
\hline & C & C & \\
\hline & OM & $U$ & \\
\hline & OM & $U$ & \\
\hline & $\mathrm{OM}$ & $U$ & \\
\hline & C & C & \\
\hline & C & $U$ & \\
\hline & $\mathrm{OM}$ & U & \\
\hline & E & U & TR \\
\hline
\end{tabular}




\begin{tabular}{|c|c|c|c|c|c|c|c|c|}
\hline 4650 & & unknown & 771 & 5.47 & 89.8 & C & $C$ & \\
\hline 4930 & & unknown & 186 & 4.70 & 19.7 & E & $U$ & \\
\hline 5300 & & unknown & 464 & 5.50 & 52.9 & $\mathrm{OM}$ & $U$ & \\
\hline 5450 & & unknown & 264 & 8.12 & 29.5 & $\mathrm{OM}$ & $U$ & \\
\hline 5460 & & unknown & 258 & 8.52 & 29.1 & C & U & \\
\hline 5570 & & unknown & 552 & 9.32 & 61.9 & $\mathrm{OM}$ & $U$ & TR \\
\hline 5580 & & unknown & 344 & 5.96 & 38.3 & $E$ & U & \\
\hline 5590 & & unknown & 213 & 8.71 & 23.9 & C & $C$ & \\
\hline 6150 & & unknown & 97 & 4.57 & 11.1 & C & $C$ & \\
\hline 6160 & & unknown & 121 & 7.07 & 13.9 & C & $C$ & \\
\hline 6200 & & unknown & 101 & 5.02 & 11.9 & C & $U$ & \\
\hline 6320 & & unknown & 105 & 5.88 & 11.9 & C & U & \\
\hline 6560 & & unknown & 295 & 6.18 & 33.7 & C & U & \\
\hline 6570 & & unknown & 212 & 4.74 & 23.8 & C & U & \\
\hline 6830 & & unknown & 109 & 4.53 & 12.3 & C & U & \\
\hline 7060 & & unknown & 546 & 5.81 & 62.7 & C & $C$ & \\
\hline 7190 & & unknown & 281 & 9.06 & 32.3 & $\mathrm{OM}$ & $C$ & \\
\hline 7200 & & unknown & 360 & 6.2 & 40.7 & $\mathrm{C}$ & $C$ & \\
\hline 7400 & & unknown & 467 & 8.61 & 52.3 & C & $U$ & \\
\hline 7650 & & unknown & 468 & 9.82 & 54.8 & E & $U$ & \\
\hline 7790 & & unknown & 234 & 5.10 & 26.4 & $\mathrm{OM}$ & U & \\
\hline 8170 & & unknown & 372 & 5.46 & 42.7 & C & IM & \\
\hline 8180 & & unknown & 150 & 8.34 & 16.3 & $\mathrm{OM}$ & $U$ & \\
\hline 8340 & & unknown & 622 & 8.64 & 70.6 & $\mathrm{OM}$ & $u$ & \\
\hline 8460 & & unknown & 56 & 4.82 & 6.4 & C & $\mathrm{C}$ & \\
\hline 8760 & & unknown & 111 & 4.09 & 12.4 & C & $\mathrm{U}$ & \\
\hline 8770 & & unknown & 177 & 4.05 & 19.8 & C & $\mathrm{C}$ & \\
\hline 8790 & & unknown & 143 & 4.69 & 16.3 & C & $\mathrm{U}$ & \\
\hline \multicolumn{9}{|c|}{ Other (immunogenic/protective against other organisms) } \\
\hline 0010 & gapB & $N A D(P)$-dependent glyceraldehyde 3-phosphate dehydrogenase $e^{c, d}$ & 335 & 7.15 & 37.3 & C & $\mathrm{C}$ & \\
\hline 1710 & $r p / L$ & $50 \mathrm{~S}$ ribosomal protein $\mathrm{L} 7 / \mathrm{L} 12^{\mathrm{e}, \mathrm{f}}$ & 131 & 5.09 & 14.3 & C & C & \\
\hline 4840 & eno & Enolase $^{\mathrm{d}, \mathrm{g}, \mathrm{h}}$ & 421 & 5.70 & 46.6 & C & $\mathrm{C}$ & \\
\hline 4860 & mraW & S-adenosyl-methyltransferase MraW (methyltransferase) ${ }^{i}$ & 301 & 9.37 & 33.7 & $\mathrm{OM}$ & $\mathrm{C}$ & \\
\hline 5160 & engA & GTP binding protein EngA (GTPase) ${ }^{i}$ & 439 & 9.26 & 50.2 & C & $\mathrm{U}$ & \\
\hline
\end{tabular}




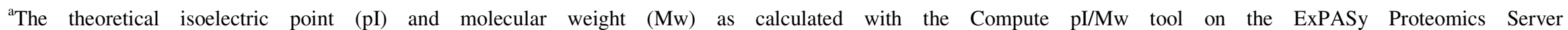
(http://us.expasy.org/tools/pi_tool.html)

${ }^{\mathrm{b}}$ Repeat sequences identified as described previously (Collins et al., 2005)

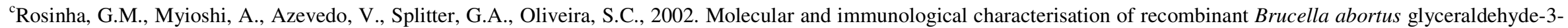
phosphate-dehydrogenase, a T- and B-cell reactive protein that induces partial protection when co-administered with an interleukin-12-expressing plasmid in a DNA vaccine formulation. J. Med. Microbiol. 51, 661-671.

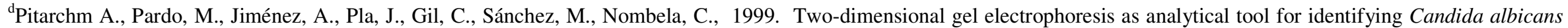
immunogenic proteins. Electrophoresis 20, 1001-1010.

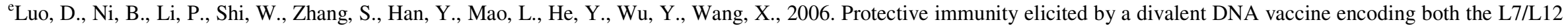
and Omp16 genes of Brucella abortus in BALB/c mice. Infect. Immun. 74, 2734-2741.

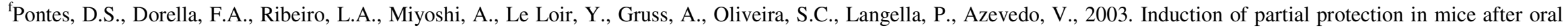
administration of Lactococcus lactis producing Brucella abortus L7/L12 antigen. J. Drug Target 11, 489-493.

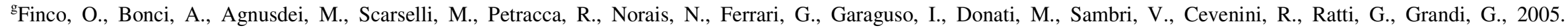
Identification of new potential vaccine candidates against Chlamydia pneumoniae by multiple screenings. Vaccine 23, 1178-1188.

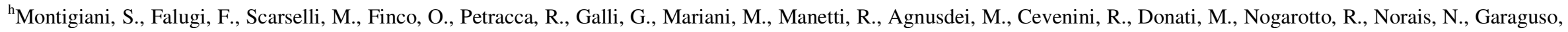
I., Nuti, S., Saletti, G., Rosa, D., Ratti, G., Grandi, G., 2002. Genomic approach for analysis of surface proteins in Chlamydia pneumoniae. Infect. Immun. 70, 368-379.

${ }^{\mathrm{i}}$ Garbom, S., Forsberg, A., Wolf-Watz, H., Kihlberg, B.M. 2004. Identification of novel virulence-associated genes via genome analysis of hypothetical genes. Infect Immun. $72(3): 1333-40$. 